\title{
Baseline assessment of coastal water quality, in Vanuatu, South Pacific: Insights gained from in-situ sampling
}

\author{
Michelle Devlin ${ }^{\mathrm{a}, \mathrm{b}, \mathrm{c}, *}$, Andy Smith ${ }^{\mathrm{a}}$, Carolyn A. Graves ${ }^{\mathrm{a}, \mathrm{b}}$, Caroline Petus ${ }^{\mathrm{c}}$, Dieter Tracey ${ }^{\mathrm{c}}$, \\ Michael Maniel $^{\mathrm{d}}$, Eryn Hooper ${ }^{\mathrm{e}}$, Krishna Kotra ${ }^{\mathrm{f}}$, Erie Samie ${ }^{\mathrm{d}}$, David Loubser ${ }^{\mathrm{g}}$, Brett P. Lyons ${ }^{\mathrm{h}}$ \\ ${ }^{\text {a }}$ Centre for Environment, Fisheries and Aquaculture Science, Pakefield Road, Lowestoft, UK \\ ${ }^{\mathrm{b}}$ Marine Collaborative Centre for Sustainable Use of the Seas (CCSUS), School of Environmental Sciences, University of East Anglia, Norwich, UK \\ ${ }^{\mathrm{c}}$ Centre for Tropical Water \& Aquatic Research (TropWATER), Townsville, Australia \\ ${ }^{\mathrm{d}}$ Department of Water Resources, Ministry of Lands and Natural Resources, Port Vila, Vanuatu \\ ${ }^{\mathrm{e}} \mathrm{C}_{2} \mathrm{O}$ Pacific, Port Vila, Vanuatu \& Auckland, New Zealand \\ ${ }^{\mathrm{f}}$ School of Biological and Chemical Sciences, Faculty of Science, Technology and Environment, The University of the South Pacific, Emalus Campus, Port Vila, Vanuatu \\ ${ }^{\mathrm{g}}$ Ecosystem Services Ltd, P.O. Box 25126, Wellington, 6140, New Zealand \\ ${ }^{\mathrm{h}}$ Centre for Environment, Fisheries and Aquaculture Science, Barrack Road, Weymouth, Dorset DT4 8UB, UK
}

\section{A R T I C L E I N F O}

\section{Keywords:}

Water quality

Eutrophication

Human health

Vanuatu

Pacific

Remote sensing

Commonwealth marine economies

\begin{abstract}
A B S T R A C T
Nearshore deterioration of water quality in Pacific coastal waters is a growing problem, associated with increasing urban and industrial sewage discharges, and agricultural runoff. Published water quality studies in the Pacific region are limited in both number and scope, making it difficult to resolve the extent of the issue or quantify the variability of water quality across Pacific islands and countries. This study collected water quality measurements over three years in the coastal waters around the Island of Efate (Vanuatu) with majority of work carried out in Port Vila, its capital. Port Vila is the key urban centre for Vanuatu where the increasing population and pollution inputs are placing substantial pressure on the coastal environment. Highest concentrations of dissolved nutrients and suspended sediments were measured adjacent or near the urban drains that enter the coastal areas along the capital's seafront, highlighting many of the issues around anthropogenic inputs are linked to the increasing urbanisation in Port Vila Bay. We provide baseline data that explores variability of coastal water quality and these types of datasets for Pacific islands are a first step towards facilitating development of long-term monitoring programmes and informing coastal zone management decision making.
\end{abstract}

Pacific countries and their marine waters have high environmental and human value, with vast areas of marine habitats, coastal waters, vulnerable ecosystems and biota (Tsamenyi and Jit, 2011). A large proportion of the Pacific community live close to the sea or are highly dependent on their association with it (Bell et al., 2011; Donnelly et al., 2012; Muckle et al., 2015) with human wellbeing being intrinsically linked to the health of the marine oceanscape. Whilst there are several ongoing research programs in the Pacific that target climate change, water quality and habitat loss, it is difficult to adequately report on the 40 million $\mathrm{km}^{2}$ area of the Pacific oceanscape (Tsamenyi and Jit, 2011). There is an urgent need for accessible water quality data and improved understanding of the impacts of pollution to ensure good environmental health and human wellbeing and to support sustainable fishing and tourism (Komugabe-Dixson et al., 2019; Mcleod et al., 2019).

The Commonwealth Marine Economies (CME) Programme was initiated in the Pacific in 2016 with funding from the United Kingdom government (McManus et al., 2019). The aim of the programme was to provide Commonwealth Small Island Developing States (SIDS) with improved hydrographic and scientific data relating to their marine environments. This approach to the collection and dissemination of scientific data aligns well with the objectives laid out in Salpin et al. (2018), who identified that the opportunity for Pacific Small Island Developing States (PSIDS) to undertake and benefit from marine science, including accessing appropriate technology, represents a significant contribution to their sustainable development aspirations. Many components of ecological measurements in Pacific countries were carried out under this program, with detailed summaries of the programme outputs presented in technical reports (Devlin et al., 2018; McManus et al., 2019) and several published papers including modelling of pollutant dispersal (Graham et al., 2020), seagrass mapping and evaluation (CMEP, 2019a, 2019b), climate change report cards (Townhill et al., 2020) and socio-economic assessments (Tyllianakis

\footnotetext{
* Corresponding author at: Centre for Environment, Fisheries and Aquaculture Science, Pakefield Road, Lowestoft, UK.

E-mail addresses: michelle.devlin@cefas.co.uk (M. Devlin), dave@ecosystem-services.co.nz (D. Loubser).
} 


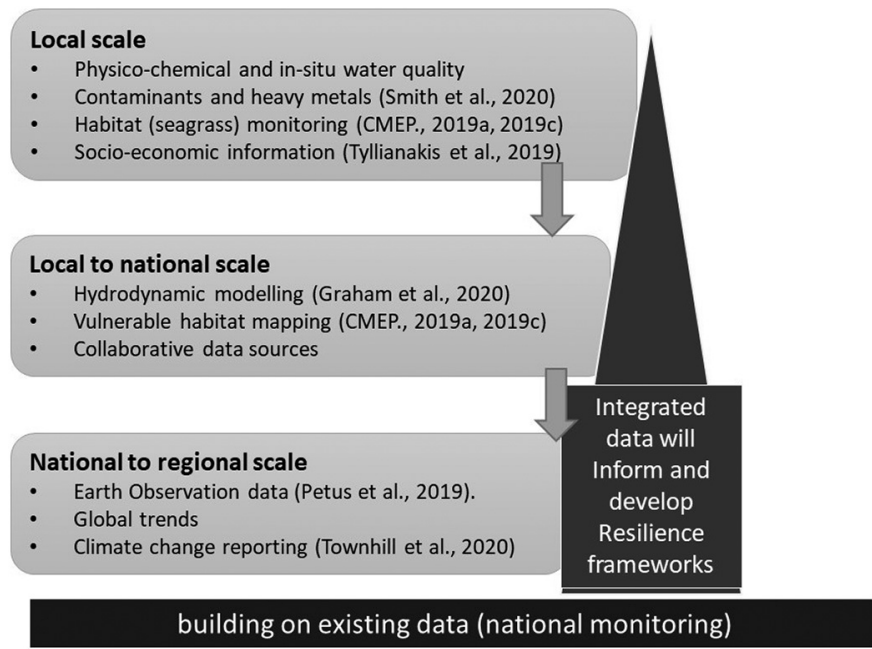

Fig. 1. Summary of the datasets collected within the Commonwealth Marine Economies Programme to provide information on Pacific water quality and habitats. Whilst much of the work has been reported separately, the long term aim of the program is to integrate all data into a wider regional summary of water quality issues, the extent of pollution and impacts on resilience in coastal ecosystems.

et al., 2019) (Fig. 1). This paper presents baseline water quality data focusing on nutrients and sediment parameters collected in Efate. The data are discussed in the context of the broader program, and water quality outcomes compared against other studies in the programme to provide further validation of the baseline data analysis.

The water quality parameters that were measured under this program include physico-chemical data, dissolved and particulate nutrients, suspended sediment and chlorophyll-a, all of which are commonly used measures of eutrophication and general water quality assessments (Brodie et al., 2010; Devlin et al., 2007; Foden et al., 2010). Additional water quality related information on human health metrics (microbial contamination) and metal and chemical contaminant concentrations (persistent organic pollutants) were also collected and are reported elsewhere, (Devlin et al., 2018; Devlin et al., 2020; CMEP, 2019a, 2019b; Graham et al., 2020; Smith et al., 2020; Townhill et al., 2020). This water quality data, in addition to the nutrient and sediment data presented here, provided information on the pressures that may influence the resilience of vulnerable ecosystems in Vanuatu, such as the seagrass beds and coral reefs (CMEP, 2019a, 2019b). These water quality parameters, the connections between the different measurements and the underlying linkages to resilience are summarised in Fig. 1. Setting this component in context of the work that was delivered as part of the larger research program provides additional evidence to support the outcomes of the water quality work.

Land based sources of pollution are significantly contributing to the decline of near shore coastal marine ecosystems, which, for many SIDS, provide essential goods and services for the local communities (Brodie et al., 2013; Brodie, 2016). Nearshore deterioration of water quality can result from sewage discharges, industrial waste discharges, dredge spoils, and agricultural and urban runoff (Brodie et al., 2013; Islam and Tanaka, 2004; Mallin et al., 2000). When coastal water quality is poor, the ability of Pacific coastal ecosystems to support healthy fisheries, aquaculture, recreational opportunities, tourism and other beneficial uses can be severely limited (Brodie, 2016; Naidu et al., 1991; Tsamenyi and Jit, 2011). The scale and severity of water quality issues can be exacerbated when it occurs in combination with warming waters and loss of resilience through climate change impacts (Anthony et al., 2015; Brodie et al., 2020Johnson et al., 2020; MacNeil et al., 2019; Ortiz et al., 2018; Townhill et al., 2020; Wolff et al., 2018).

Sewage is one of the most significant source of coastal pollution across the Pacific region (Brodie, 2016; Carter, 1990; Chape, 2006; Koshy et al., 2006). The causes of sewage pollution include overflowing latrines, septic systems, low functioning sewage treatment plants, as well as the lack of sanitation facilities (Fujita et al., 2013; HerreraSilveira et al., 2004; Islam and Tanaka, 2004; Komugabe-Dixson et al., 2019; Mimura, 2006; Mosley and Aalbersberg, 2003). Nearly every Pacific island nation has identified critical environmental and public health problems resulting from the disposal of human related sewage (Brodie, 2016; Fujita et al., 2013; Naidu et al., 1991; Palanaippan et al., 2017; UNEP, 1999). These have included algae blooms and eutrophication in lagoons, deteriorating coral reef health, contaminated drinking water in wells and outbreaks of gastro-intestinal disease and cholera in human populations in contact with the polluted water (Amato et al., 2020; Barnes et al., 2019; Fujita et al., 2013; Greenhill et al., 2019; Mosley and Aalbersberg, 2003; Quimpo et al., 2020; Singh and Mosley, 2003; Yoshioka et al., 2016). Sewage pollution is considered one of the more serious human environmental problems, responsible for a high prevalence of water-related diseases (Morrison, 2016; Naidu et al., 1991; Poustie et al., 2016).

Vanuatu, is an island country, located in the South Pacific. It comprises six provinces, spread across 82 islands with the capital Port Vila located on the island of Efate. The total population of Vanuatu in the 2009 census was 234,023 , with an average annual growth rate of $2.3 \%$, and the highest proportion found in Port Vila (51,440 people, 2016 census) and Luganville (16,310, 2016 census). Vanuatu, as with most Pacific countries, is experiencing an increase in coastal water quality related issues corresponding to a rising population and a lack of infrastructure to deal with the additional population pressures (Brodie et al., 2020; Carter, 1990; Kenter et al., 2011; Poustie and Deletic, 2014). Unmanaged and uncontrolled sanitation and wastewater in Vanuatu are major concerns, particularly in relation to human health and ongoing impacts on the tourism industry. Outside of urban centres, water supply systems are either poor or non-existent and water quality is sub-standard and prone to contamination, mostly from human and animal waste (FAO, 2016). In both Port Vila and Luganville, groundwater levels are decreasing as demand for water rises. There are currently no regulations for wastewater management or monitoring, and most of Port Vila and Luganville lack sewage and wastewater treatment systems. As a result, waste is usually disposed of via stormwater drains, directly into water sources or into septic systems that leach contaminants into coastal and freshwater systems (GSH, 2020). Recent studies have identified under-developed sanitary facilities as the source of microbial and nutrient contamination, which is carried into lagoons around Port Vila by rapid groundwater flows (Devlin et al., 2018; Graham et al., 2020; Poustie and Deletic, 2014; Poustie et al., 2016; String et al., 2020). Seepage of untreated sewage/septic systems into groundwater and stormwater drains, combined with poor natural flushing in Port Vila Bay, has resulted in microbial contamination, decreased oxygen concentrations and higher turbidity. Scabies, skin diseases and malaria are the three most common water-related health issues in Vanuatu (FAO, 2016; Mateo-Sagasta et al., 2017). Poor drainage and waste management are also a source of pools of water that are favourable breeding sites for malaria-carrying mosquitos. Agriculture is important for Vanuatu, as one of the main contributors to the economy. $80 \%$ of the population is engaged in agricultural activities that range from subsistence farming to smallholder farming of coconuts and other cash crops. Copra is by far the most important cash crop (making up more than $35 \%$ of Vanuatu's exports), followed by timber, beef, and cocoa (Anon, 2019). Changes in the type of agriculture has had significant impact on the downstream environment. Practices such as slash-and-burn agricultural practices, a cultivation technique in which trees are cut down and burned in order to clear land for temporary agriculture is one such activity that has contributed to increased discharges of fine sediment and particulate nutrients into coastdal environment (Anon, 2019).

Water quality data was collected during surveys conducted between 
Table 1

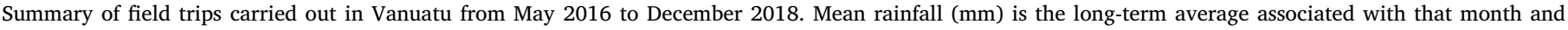
monthly rainfall $(\mathrm{mm})$ is the average reported rainfall for Vanuatu in the specific month and year.

\begin{tabular}{|c|c|c|c|c|c|c|c|c|c|}
\hline $\begin{array}{l}\text { Programme } \\
\text { Year }\end{array}$ & Country & Focus area & Trip & Year & Month & Season & Sites & Mean Rainfall (mm) & $\begin{array}{l}\text { Monthly Rainfall } \\
\text { (mm) }\end{array}$ \\
\hline 1 & Vanuatu & Efate & $\mathrm{T} 1$ & 2016 & May & Autumn & 33 & 160 & 26.6 \\
\hline 1 & Vanuatu & Efate & $\mathrm{T} 2$ & 2016 & August & Winter & 39 & 113 & 34.9 \\
\hline 2 & Vanuatu & Port Vila & $\mathrm{T} 3$ & 2017 & July & Winter & 30 & 125 & 16.2 \\
\hline 2 & Vanuatu & Port Vila & $\mathrm{T} 4$ & 2017 & September & Spring & 53 & 111 & 11.1 \\
\hline 2 & Vanuatu & Port Vila & T5 & 2017 & December & Summer & 53 & 206 & 79.5 \\
\hline 3 & Vanuatu & Port Vila & $\mathrm{T} 6$ & 2018 & August & Winter & 35 & 113 & 22.3 \\
\hline 3 & Vanuatu & Port Vila & $\mathrm{T} 7$ & 2018 & September & Spring & 48 & 111 & 56.5 \\
\hline 3 & Vanuatu & Port Vila & $\mathrm{T} 8$ & 2018 & November & Summer & 11 & 167 & 73.8 \\
\hline 3 & Vanuatu & Tanna & T9 & 2018 & December & Summer & 45 & 206 & 248.4 \\
\hline
\end{tabular}

May 2016 and January 2019 around the island of Efate, Vanuatu (Table 1), with a single survey of the island of Tanna. The two initial trips (T1, T2) in Vanuatu in May and August 2016 collected data from around Efate (Fig. 2), including North Efate, Mele and Port Vila. Trips between July 2017 and November 2018 (T3, T4, T5, T6, T7, T8) focused on 4 sites in North Efate (NE), 16 sites within Mele Bay, 20 sites within Port Vila Bay, 18 river sites, 5 sites within the lagoon system and 10 sites located at close proximity to Port Vila outlet drains, Sites designated as Port Vila Drains were located at the outflow of the stormwater drains as they entered the area of Port Vila Bay (Fig. 2). Samples (45) were also collected around Tanna in December 2018 (T9) only. Higher resolution maps of all sites and areas are found in Supplementary Fig. 1 (Efate) and Supplementary Fig. 2 (Tanna). Not all sites were sampled during every survey nor was the full set of parameters collected at every site, due to logistics, weather and boat availability.

A series of physical and chemical variables were measured either insitu or analysed from seawater samples. Depth profiles were obtained using an ESM2 profiler, a Cefas developed micro-logger with standard sensors for conductivity, temperature, depth, optical backscatter and roll \& pitch, for T1 and T2 (Sivyer et al., 2016), a RBR Maestro for T6 and an RBR Concerto for T9 (RBR Ltd., Canada). Makes and models of the different sensors are detailed in Table 2. Additional surface-only temperature and salinity measurements were collected using hand-held probes (Hanna, SAIV 200, WTW-Multiline 3630 IDS and 3460, BACTI Wader Pro). Water samples were also collected for dissolved inorganic nutrients (DIN), total suspended solids (TSS) and chlorophyll-a (Chl-a). The dissolved nutrient parameters were nitrate + nitrite $\left(\mathrm{NO}_{\mathrm{x}}\right)$, ammonia $\left(\mathrm{NH}_{4}\right)$, dissolved inorganic nitrogen (DIN:as the sum of $\mathrm{NO}_{\mathrm{x}}$ and $\mathrm{NH}_{4}$ ), dissolved inorganic phosphate (DIP) and silicate $\left(\mathrm{SiO}_{4}\right)$.

Within six hours of sampling, water samples collected for the analysis of chlorophyll concentration were filtered (on GFC filters) and stored frozen until pigment concentration was determined by fluorometric technique, following maceration of algal cells and pigment extraction in acetone (Parsons, 2013). A Turner 10-005R fluorometer was used for the analysis and was periodically calibrated using chlorophyll extracts prepared from log-phase diatom cultures (Jeffrey and Humphrey, 1975). After filtration of known volume of water samples, concentrations of TSS were determined gravimetrically from the difference between loaded and unloaded membrane filter weights after drying filters at $60{ }^{\circ} \mathrm{C}$ for a minimum of $12 \mathrm{~h}$.

Nutrient concentrations were determined using standard procedures (Ryle and Wellington, 1982) with a Skalar San ++ continuous flow analyser (Skalar Analytical, Breda, The Netherlands). Detection limits were $0.006 \mathrm{mg} / \mathrm{L}$ for $\mathrm{NH}_{4}, 0.01 \mathrm{mg} / \mathrm{L}$ for $\mathrm{NO}_{\mathrm{X}}$ and $0.01 \mu \mathrm{g} / \mathrm{L}$ for DIP. Artificial seawater was used to establish baseline characteristics. Analyses of the total dissolved nutrients (total dissolved nitrogen species and total dissolved phosphate species) were carried out using persulfate digestion of the water samples (Valderrama, 1981) and samples were then analysed for inorganic nutrients, as above.

Water quality data was collected from 70 sites in Efate and 35 sites in Tanna with site information presented in supplementary data. Water quality paramaters were summarised by site and sampling date and calculated as mean and standard error. Data from each of the 70 sites were aggregated into six distinct reporting areas around Efate and one area for the 35 sites in Tanna with water quality parameters reported as the mean and standard error within each of the six reporting areas. The six reporting areas in Efate were classified as North Efate, Mele Bay, Rivers, Lagoons, Port Vila Bay and Port Vila Drains (Fig. 2). A single reporting area was assigned to all the Tanna sites. We use a data visualisation technique to illustrate the magnitude of the concentrations associated with three of the water quality parameters $\left(\mathrm{NO}_{\mathrm{X}}, \mathrm{NH}_{4}\right.$, DIN) across the Efate sampling areas. This technique, known as heat maps, provides a visual overview of how the water quality concentrations are clustered or vary.

Efate has very consistent air temperatures throughout the year (Fig. 3a), but rainfall reflects the seasonal influences associated with the monsoon (Fig. 3b). March is usually the wettest month in Efate with $37 \mathrm{~cm}$ on average. The sea is usually at its warmest in Efate in February when the water temperature typically reaches $29{ }^{\circ} \mathrm{C}$. The monthly rainfall for the sampling trips T1 to T8 were all below the long term annual average (Table 1, Fig. 3) with the exception of T9 (December 2018).

Depth profiles of the water column structure were measured at the deeper water sites (depth $>2 \mathrm{~m}$ ) through the deployment of the ESM2 or RBR sensor packages measuring temperature, salinity, dissolved oxygen, turbidity and fluorescence (Fig. 4). Depth profiles of photosynthetically active radiation (PAR) were also measured (not shown) and used to estimate light attenuation (Kd) (Fig. 4). Turbidity is given in Nephelometric Turbidity Units (NTU), proportional to scattered light, and Chlorophyll as fluorescence in sensor factory-calibrated units, which are proportional to $\mu \mathrm{g} / \mathrm{L}$ chl-a. Dissolved oxygen was calibrated by pre-and post-survey two-point calibration, which while sub-optimal for these sensors (which would ideally be calibrated daily in-situ), provides a lower-precision overview of the oxygen conditions and a consistent picture across surveys.

The depth profiles have allowed identification of where stratification is occurring (Fig. 4). The profiles indicate that the system is highly dynamic; with shallow coastal waters tending to be well mixed, and stratification occurring further offshore. Salinity and temperature were influenced by location and proximity to freshwater inputs, with evidence of a shallow warm and fresh surface layer at some sites. Around Tanna, the influence of volcanic hot freshwater streams mixing with the seawater is evident at some sites on the east of the island. Turbidity was varied with depth and was typically highest near the surface. There were differences in turbidity between sites, with deeper Mele Bay sites furthest from shore having the clearest waters. Mele Bay waters were much more turbid in May 2016 than August 2016 (mean profile turbidity for 5-16.5 m water depth across sampled stations of $0.7 \pm 0.05$ and $0.3 \pm 0.08 \mathrm{NTU}$, respectively), which may reflect the dry season conditions in August. Chlorophyll fluorescence also often varied with depth, with some sites showing subsurface peaks, and others increases towards the seabed. The highest chlorophyll in profiles shown in Fig. 4 

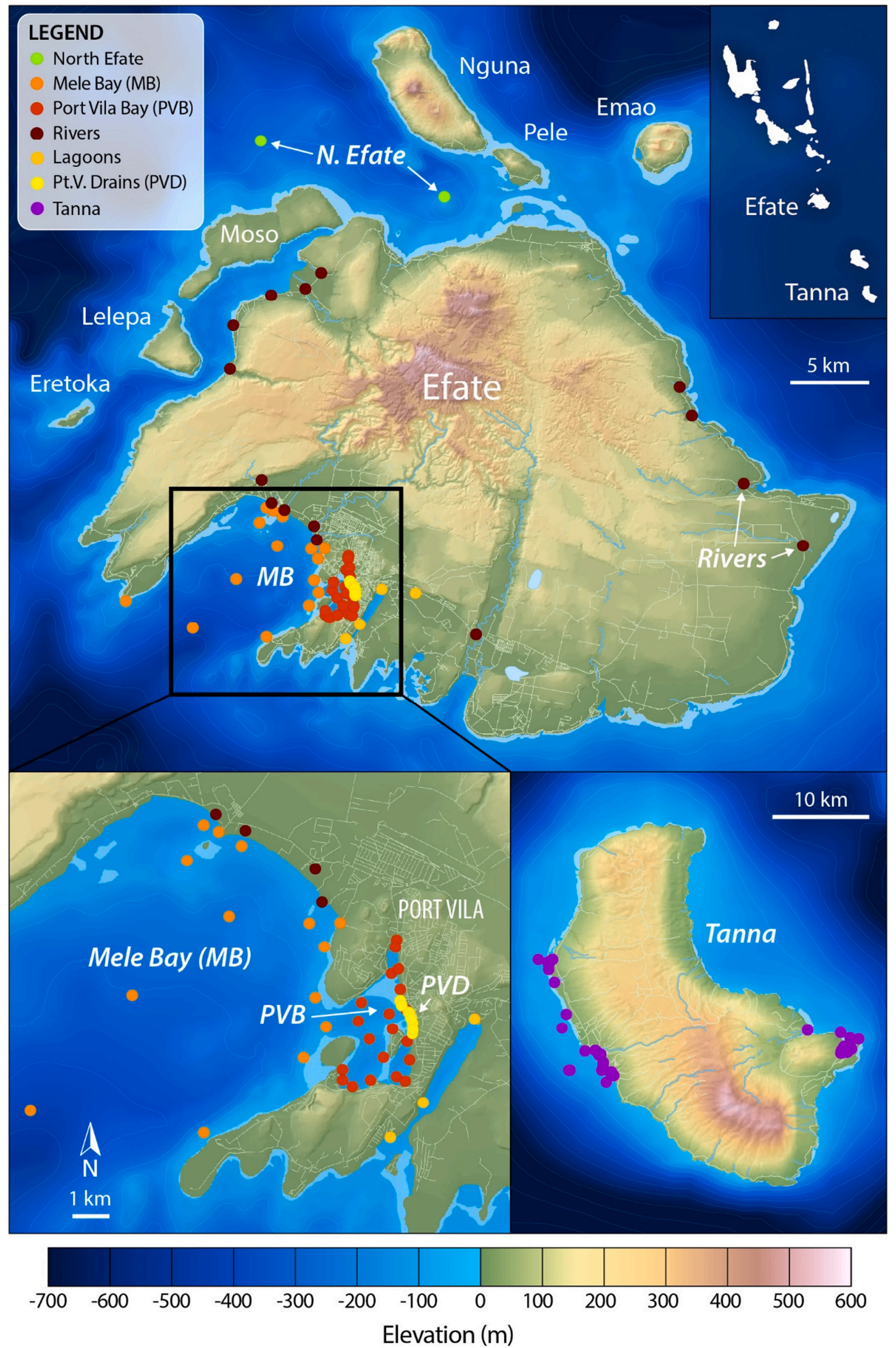


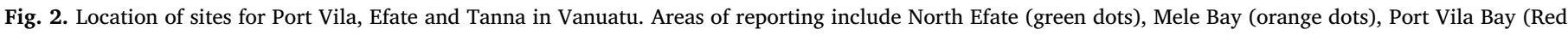

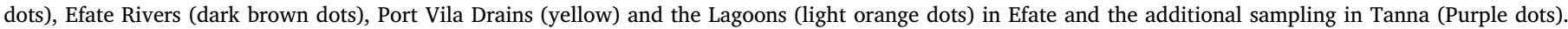

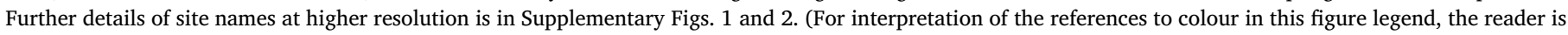
referred to the web version of this article.)

Table 2

Details of sensors used on each profiler (ESM2, RBR Concerto and RBR Maestro) over the duration of the study.

\begin{tabular}{|c|c|c|c|}
\hline Parameter & Sensor & Profiler & Company \\
\hline \multirow[t]{2}{*}{ Temperature and Salinity } & FSI CT & ESM2 & Falmouth Scientific, Inc., USA \\
\hline & RBR Marine CT & RBR instruments & RBR Ltd., Canada \\
\hline Turbidity & Seapoint STM & All & Seapoint Sensors Inc., USA \\
\hline \multirow[t]{3}{*}{ Dissolved Oxygen } & Aanderaa 4330F Optode & ESM2 & Aanderaa Data Instruments AS, Norway \\
\hline & RBRcodaT.ODO & RBR Concerto & RBR Ltd., Canada \\
\hline & RBRcodaODO|fast8 & RBR Maestro & \\
\hline \multirow[t]{2}{*}{ Chlorophyll } & Seapoint flurometer & ESM2 & Seapoint Sensors Inc., USA \\
\hline & Turner Cyclops flurometer & RBR Maestro & Turner Designs Inc., USA; Maestro \\
\hline PAR & Li-Cor LI-192 PAR & ESM2 and RBR Maestro & LI-COR Biosciences, USALI-COR Biosciences, USA \\
\hline
\end{tabular}

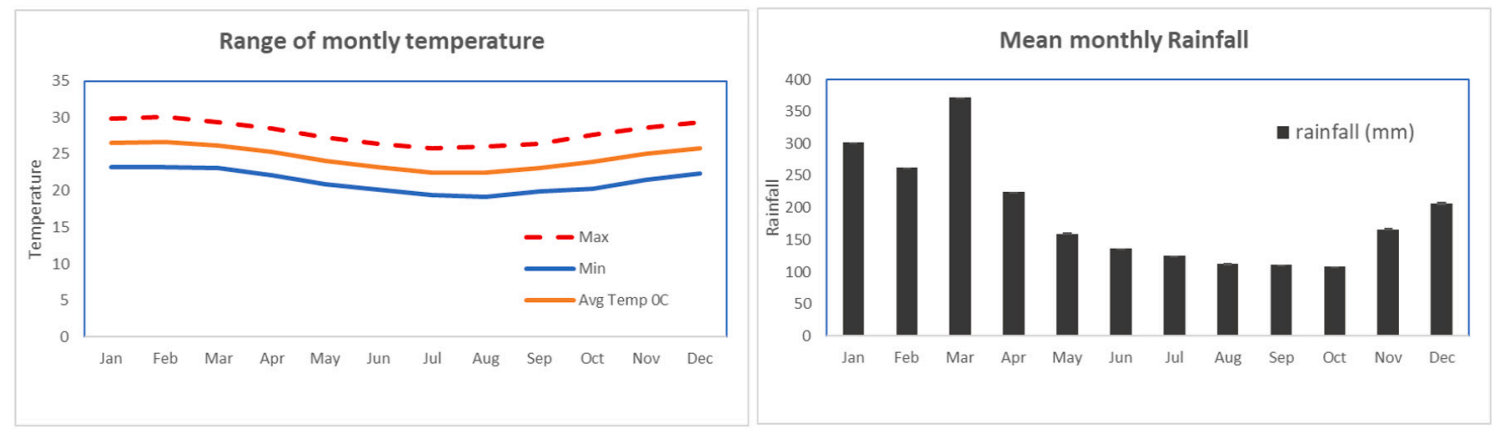

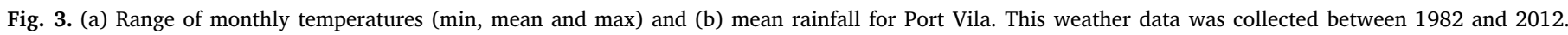
Monthly minimum and maximum temperatures and monthly average rainfall were taken from https://en.climate-data.org/info/sources/

was observed at Central PVB sites, however much higher values were observed throughout the water column in Fatumaru Bay (data not shown as exceeds plot axis scale). Only one depth profile was obtained from Fatumaru Bay - an area of restricted circulation in Northern Vila Bay which is cut off by a shallow coral sill a low tide. Here, throughout the 4-m deep water column, salinity was lower than PVB sites $(<33.5$ PSU) and temperatures more than 1 degree higher than the adjacent PVB stations, turbidity was 2-10 times higher than at all other sites and chlorophyll 2 times higher at depth but exceeding 100 times higher at the surface. The water was typically well-oxygenated, though some PVB sites did show evidence of oxygen depletion with depth which could be related to eutrophication issues, with Fatumaru Bay being among the most notable.

Depth profiles of these key parameters are a valuable resource as they provide multiple data points with high spatial coverage and information on the vertical dynamics and stratification. This physiochemical data has been used in the validation of the hydrodynamic modelling (particle transport) (Devlin et al., 2018; Graham et al., 2020). Sensors which measure conductivity, temperature, and pressure (CTD) are not dependent on more labour intensive in-situ water sampling, so more observations can be retrieved via this method. Validation from in-situ sampling data is useful for calibration but cross validation of multiple parameters collected from high frequency instrumentation may eventually limit the need for water quality validation samples.

In-situ water quality data collected over multiple sampling dates show high variability, particularly related to nutrient concentrations that likely reflect either the seasonal influences of high rainfall or the input of stormwater via sewage disposal. Measurements averaged over each sampling date (Fig. 5) show high variability related to individual sites and some influence of seasonality. The highest peaks in $\mathrm{NO}_{\mathrm{x}}$ and $\mathrm{NH}_{4}$ (Fig. 5a) and DIP (Fig. 5b) are for dry season months in Port Vila.
Rainfall may be a factor in the higher $\mathrm{NO}_{\mathrm{x}}$ values but given the low amount of rainfall in these months, the high nutrient values are more likely influenced by the stormwater drainage system and sewage outfall. The dominant form of dissolved nitrogen is $\mathrm{NO}_{\mathrm{x}}$, with $\mathrm{NH}_{4}$ dominating in only two sampling periods (Fig. $5 \mathrm{a}$, b). Sampling was carried out during the dry season and a "dry" wet season (Table 1, Fig. 3), thus potentially missing a seasonal 'first flush' event where the highest input of pollutants would be carried into nearshore waters by the Efate Rivers and the stormwater system. The higher nutrient concentrations in a dry August highlight the effect of the stormwater drains and the acute influence of urban-related flow in dry season months where rainfall is not providing dilution (Müller et al., 2019; Poustie and Deletic, 2014; Torno et al., 2013).

The optimal DIN:DIP ratio (N/P-ratio) for phytoplankton growth is 16:1 (based on molar concentrations and referred to as the Redfield ratio), and significant deviations from 16 at low N/P-ratios indicate potential nitrogen limitation and at high N/P-ratios potential phosphorus limitation of phytoplankton primary production (Fulweiler et al., 2012). The DIN:DIP ratios measured over all sites show that nitrogen limitation is likely at most sites, but with several exceptions at PVD sites which show P limitations, suggesting continuous flows of dissolved nitrogen from the urban drains (Fig. 5, Supplementary Fig. 2).

Water quality data was aggregated into six specific areas in Efate including North Efate, Mele Bay, Rivers, Lagoons, Port Vila Sites and Port Vila Drains. Data collected in Tanna were aggregated into a single reporting area (Fig. 2, Fig. 6). The highest nutrient concentrations were measured inshore at areas close to the stormwater drains (part of the Port Vila Drain sites) and the Port Vila Bay sites. Elevated $\mathrm{NO}_{\mathrm{x}}, \mathrm{NH}_{4}$ and DIP concentrations are measured alongside the stormwater drains and reflect the high pollution potential of non-treated sewage and stormwater runoff into the Bay. The in-situ water quality data show that 

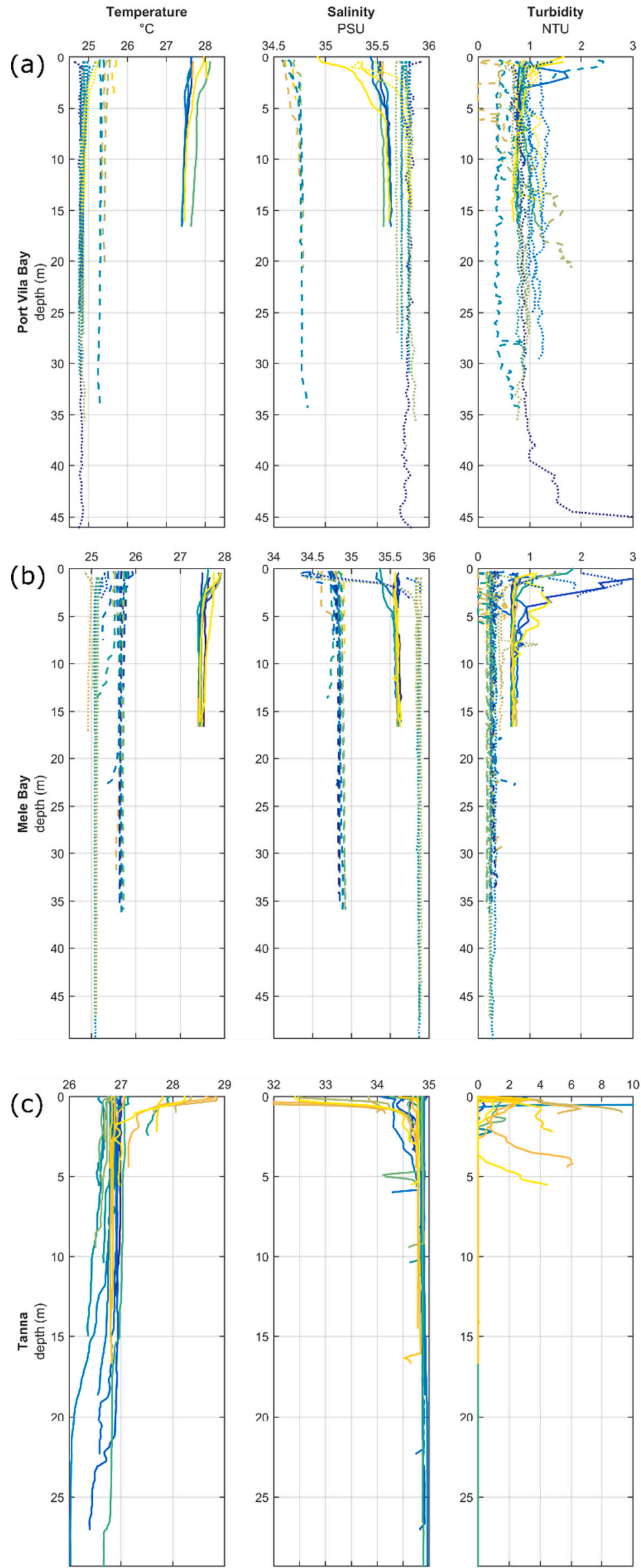
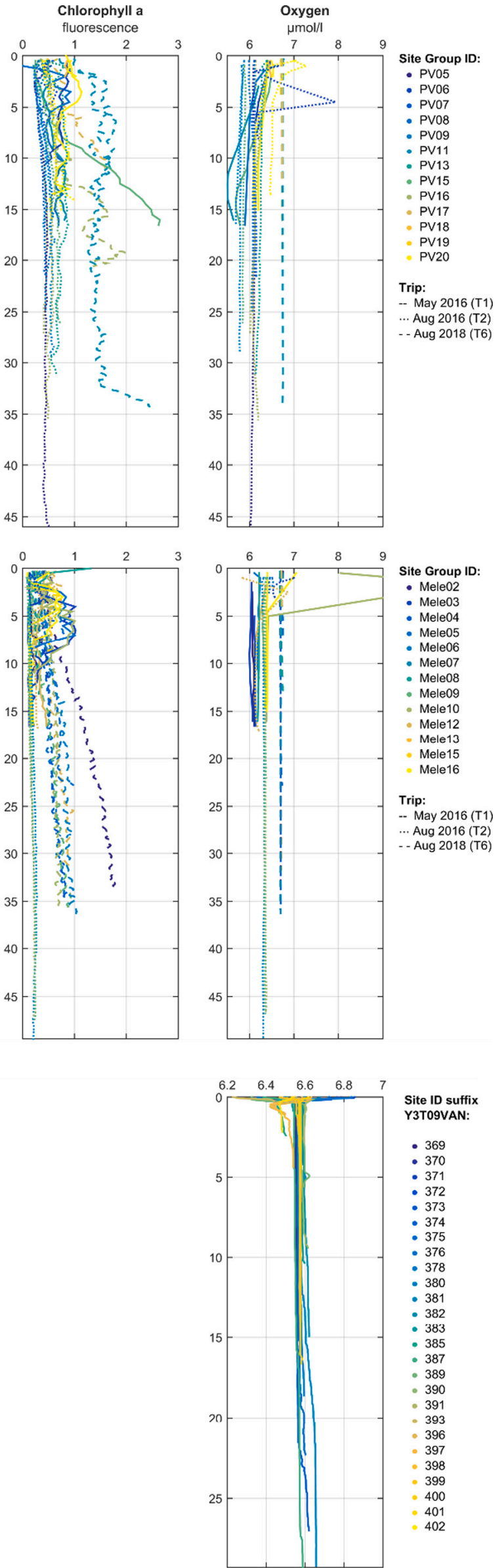

(caption on next page) 


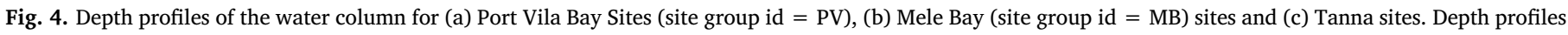
were taken in T1 (May 2016), T2 (August 2016) and T6 (August 2018).
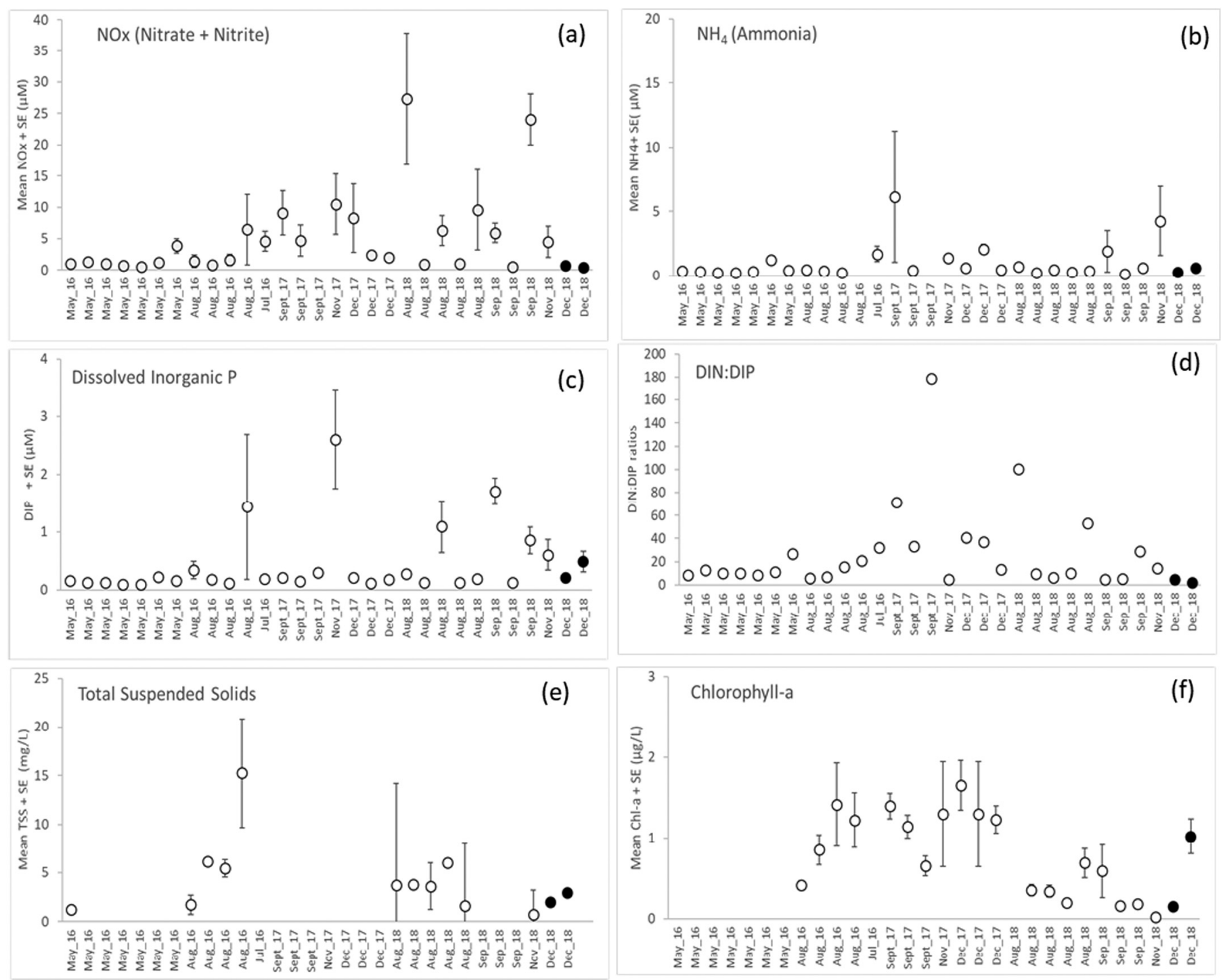

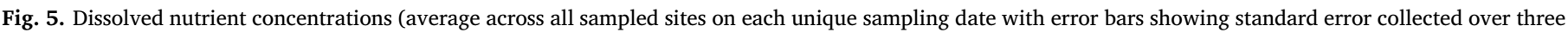

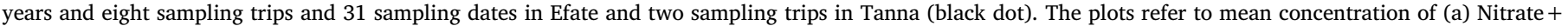

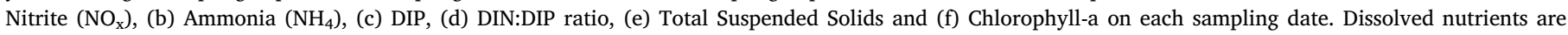

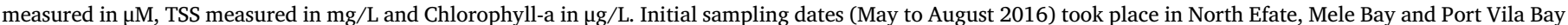
whilst the sampling from July 16 to November 18 focused on sites within Port Vila Bay, Rivers and Lagoons.

coastal nutrient pollution in Efate is elevated around the nearshore areas adjacent to the Port Vila Drains and Port Vila Bay sites with the highest nutrient concentrations measured at sites closest to the stormwater drains (Fig. 6). The mean concentrations of $\mathrm{NO}_{\mathrm{X}}$ and $\mathrm{NH}_{4}$ in the Port Vila Drains and the Port Vila Bay sites show that the highest measurements of dissolved nutrients were taken inshore and close to the discharges from the stormwater drains. However, the highest $\mathrm{NO}_{\mathrm{X}}$ measurements were in the river sites suggesting that diffuse sources (agriculture) may also be an important source of the dissolved nutrients. $\mathrm{NH}_{4}$, though lower than $\mathrm{NO}_{\mathrm{X}}$, is elevated across most of the sites in Port Vila Bay indicating that urban related sewage flows are likely to be influencing the elevated nutrient concentrations within the whole Bay. DIP concentrations are low, and nitrogen: phosphorus ratios are typically greater than 16 indicating that most of the areas are (generally) phosphate-limited other than sites which are in close proximity to the Port Vila Drains.
The spatial distribution of dissolved nitrogen concentrations is shown across all Efate sampling sites using a heat map process (Fig. 7). Localised high concentrations are shown for $\mathrm{NO}_{\mathrm{X}}$ (Fig. 7), $\mathrm{NH}_{4}$ (Fig. 7ii) and DIN (Fig. 7iii). The higher mean water quality values for dissolved nutrients (Fig. 5) align with the stronger colour in the coastal areas and illustrates that the location of the higher concentrations in Efate are in close proximity to the Port Vila drains and adjacent to the urbanised area of Port Vila (Figs. 5, 6). North Efate, Mele Bay and Tanna sites had, in comparison, very low in-situ dissolved nutrient concentrations. These outputs indicate that stormwater pollutants could be directly affecting up to $50 \%$ of Port Vila Bay area which is regularly used for inshore subsistence fishing and recreational use by the local community and discharges could thus pose a health risk to those regularly using these waters. The Fatumaru Bay area, observed to be heavily used by the local community, is notable from the high intensity colour signifying high nutrient concentrations for this area. Higher turbidity (TSS) 

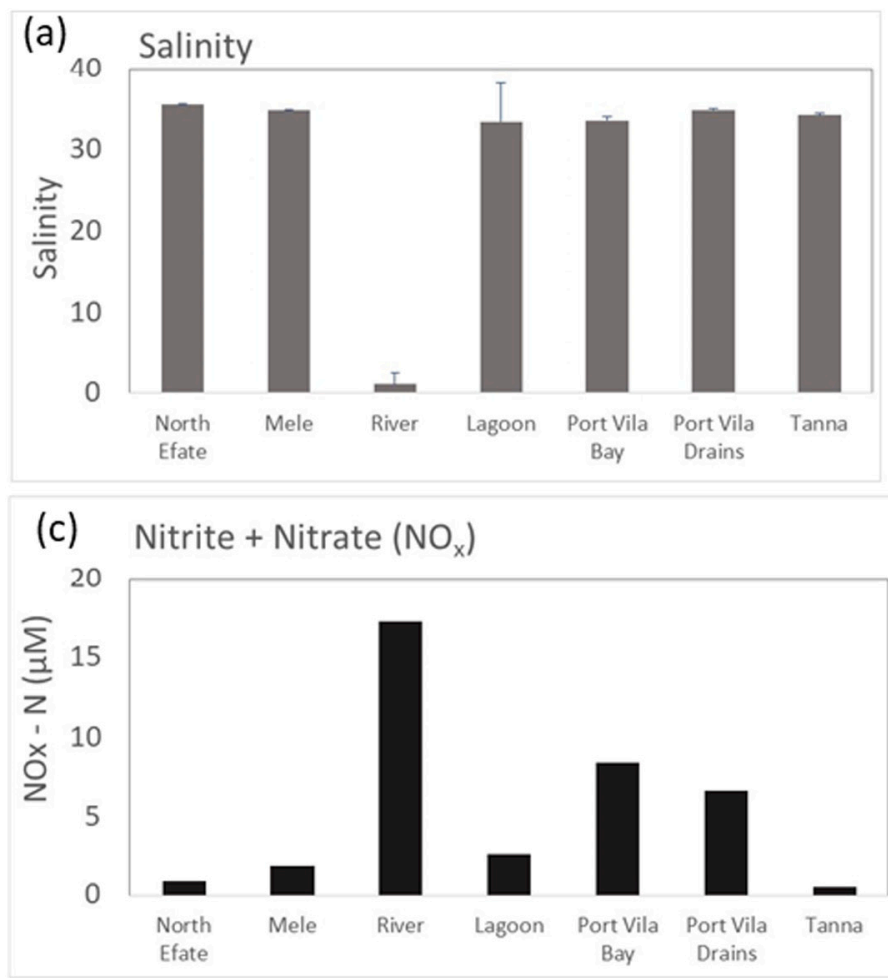

(e) Dissolved Inorganic Phosphate

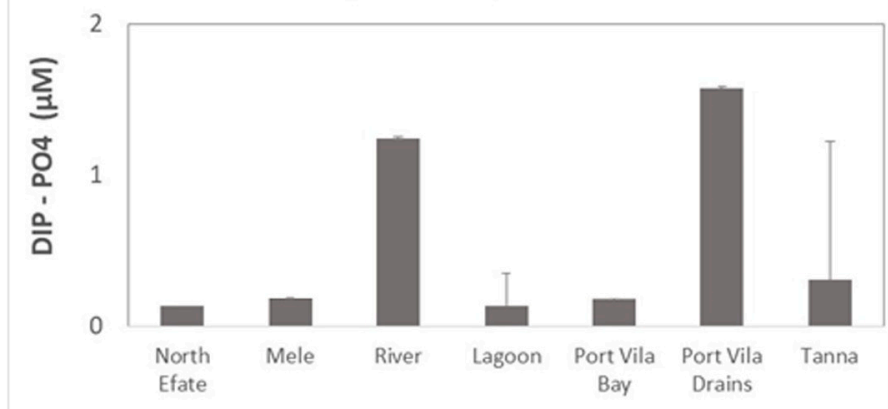

(g)

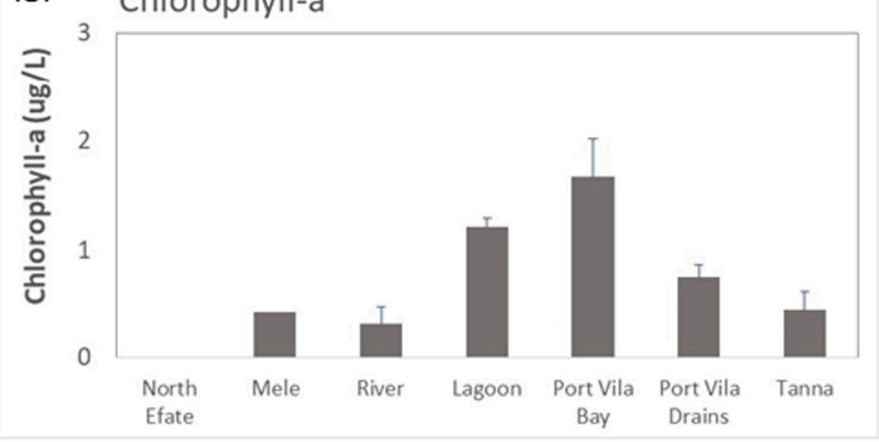

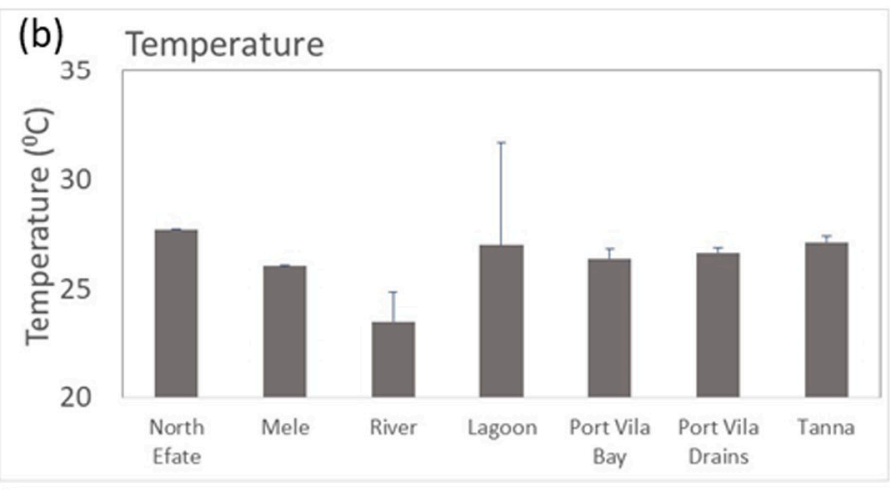

(d)

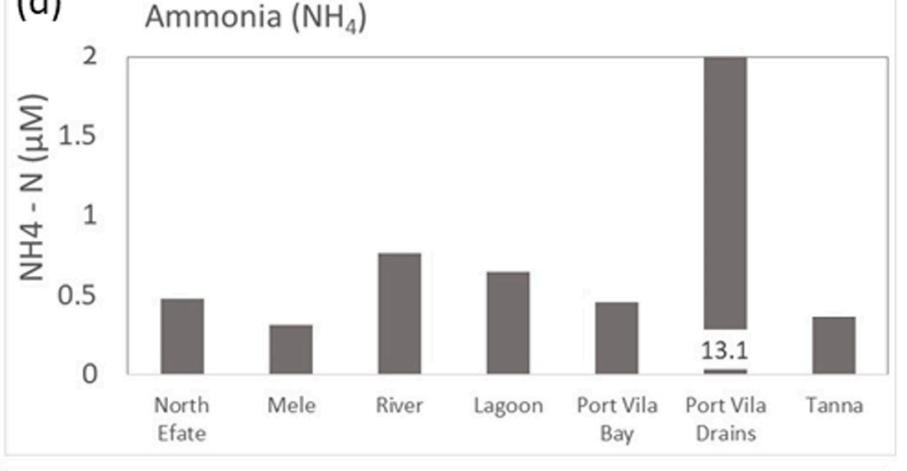

(f)

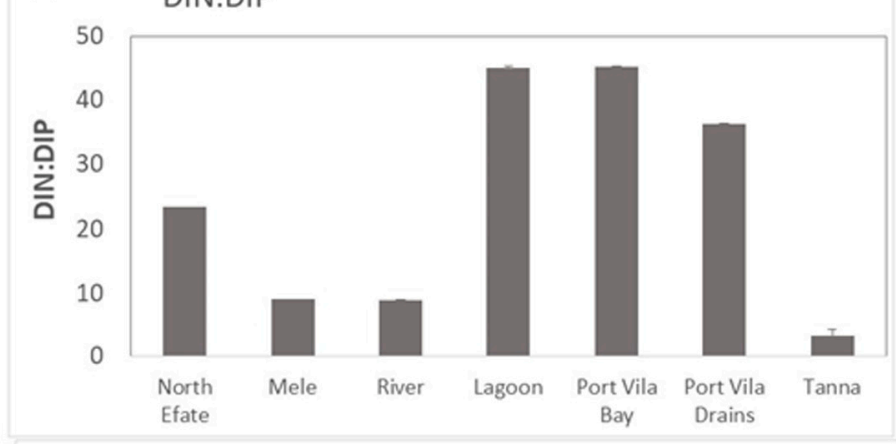

(h) Total Suspended Solids

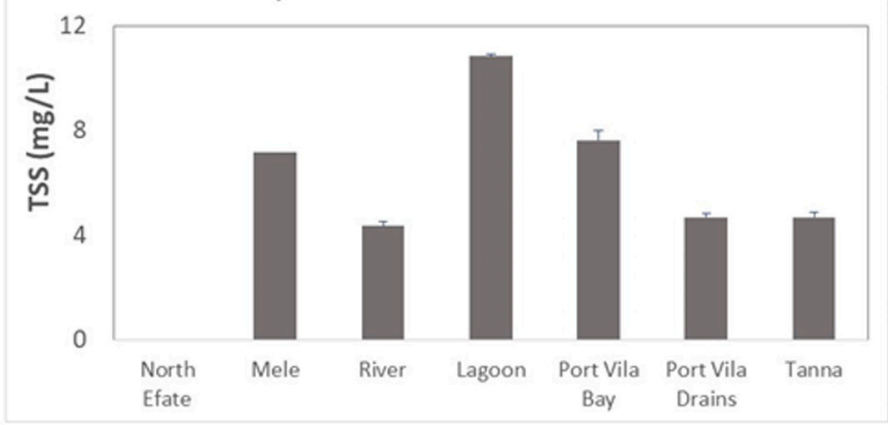

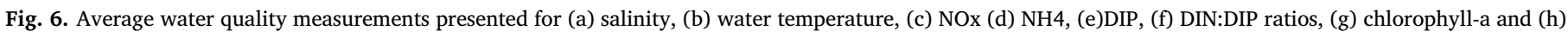

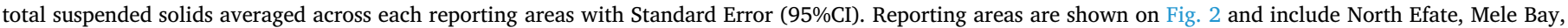
Rivers (Efate), Lagoons, Port Vila Bay, Port Vila Drains and Tanna.

concentrations, which can limit the amount of light available, are seen at sites in Fatumaru Bay, Mele Bay and in the lagoon, all areas which support seagrass habitats (Figs. 2, 4).

This study reports key water quality parameters collected as part of a larger Pacific research programme that focused on water quality issues, human health concerns and mapping of vulnerable habitat. To contribute to our findings from the water quality evaluation, we summarise water and chemical parameters that have been collected within the wider data remit of the four-year program (Table 3). We also consider the water quality data against the outcomes of a hydrodynamic model developed to model the transport and extent of pollutants in Port Vila Bay (Graham et al., 2020).

Water at many of the sites was tested for toxicity using Microtox analysis (Smith et al., 2020). The majority of sites appeared to have low 

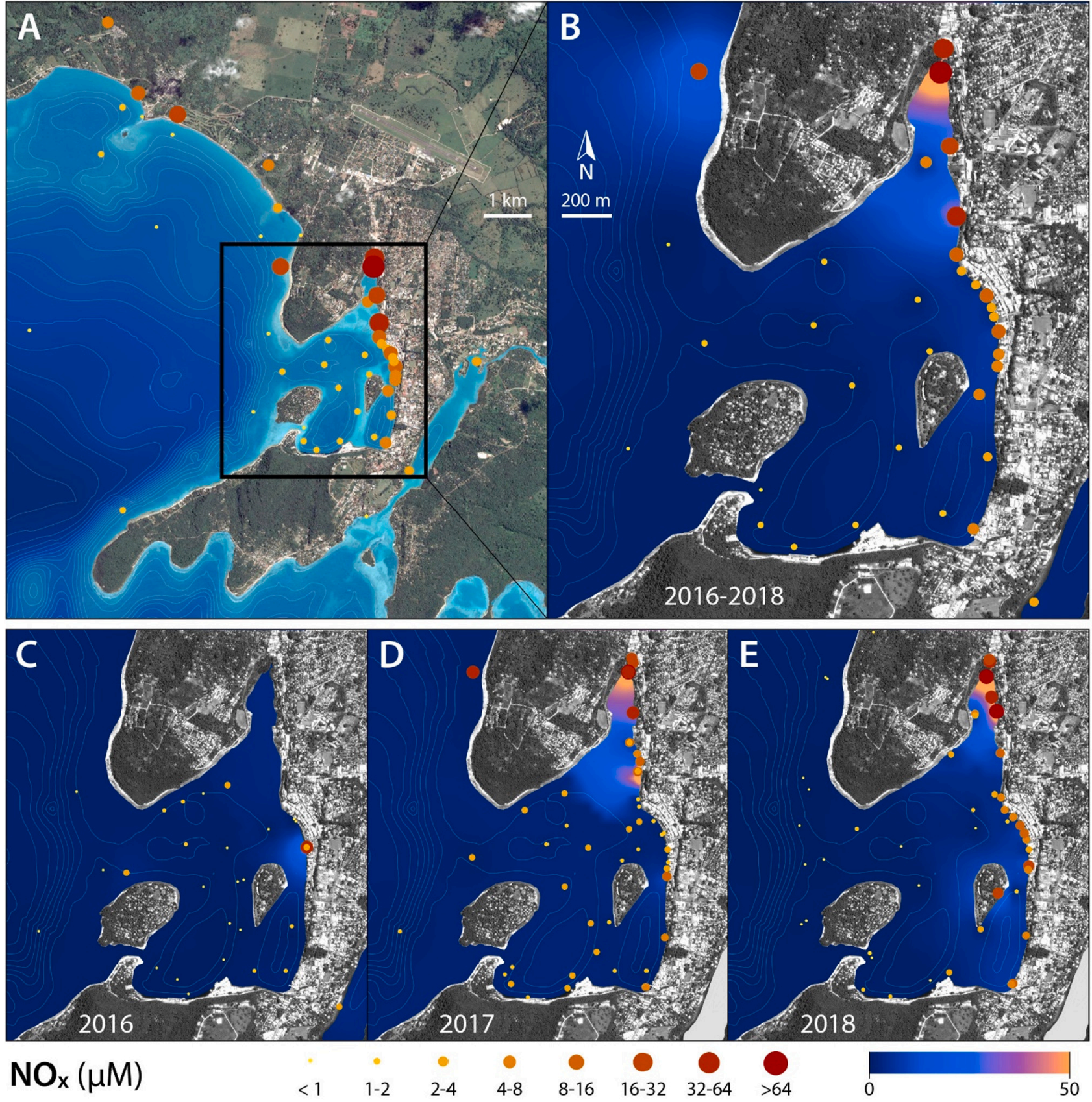

Fig. 7. Site map for (i) NOx samples, (ii) $\mathrm{NH}_{4}$ samples and (iii) DIN samples where (a) identifies the water quality samples collected around Mele Bay and Port Vila coastal waters and the inset highlights the high frequency of samples taken in Port Vila Bay. Annual heat maps are presented for (b) all years (c) 2016 and (d) 2017 and (e) 2018. Note that sampling in 2016 did not include the northern side of Port Vila Bay (Fatumaru Bay).

overall toxicity but with some notable exceptions. In particular, sites near rivers and Port Vila Drains have been identified as areas where high toxicity may be occurring and requires further investigation (Table 3).

Microbial parameters were sampled in and around Port Vila Bay. Some samples adjacent to the Port Vila drains exceeded international bathing water standards due to high values of Escherichia coli (Mansilha et al., 2009). Whilst the sampling for microbial parameters was limited, the data does show the highest concentrations of microbial contamination occur close inshore in areas that have high tourism value and easy access to swimming and snorkelling (Devlin et al., 2020) (Table 3).
The in-situ water quality outcomes support the results of the hydrodynamic modelling (Graham et al., 2020) which shows that the highest pollutant concentrations inshore of the Port Vila Bay dissipates quickly as the water moves into the outer coastal waters. Modelling of the pollutant distribution in Port Vila Bay sites (Graham et al., 2020) also identifies that these areas affected by sewage and stormwater inputs are where the highest pollutant concentrations are dispersed close to shore. The modelling indicates that stormwater pollutants could be directly affecting areas which are regularly used for inshore subsistence fishing and recreational use by the local community.

Freely accessible coarse $(1-\mathrm{km})$ to high $(20-\mathrm{m})$ resolution satellite imageries were also trialled as part of this baseline study as a cost- 

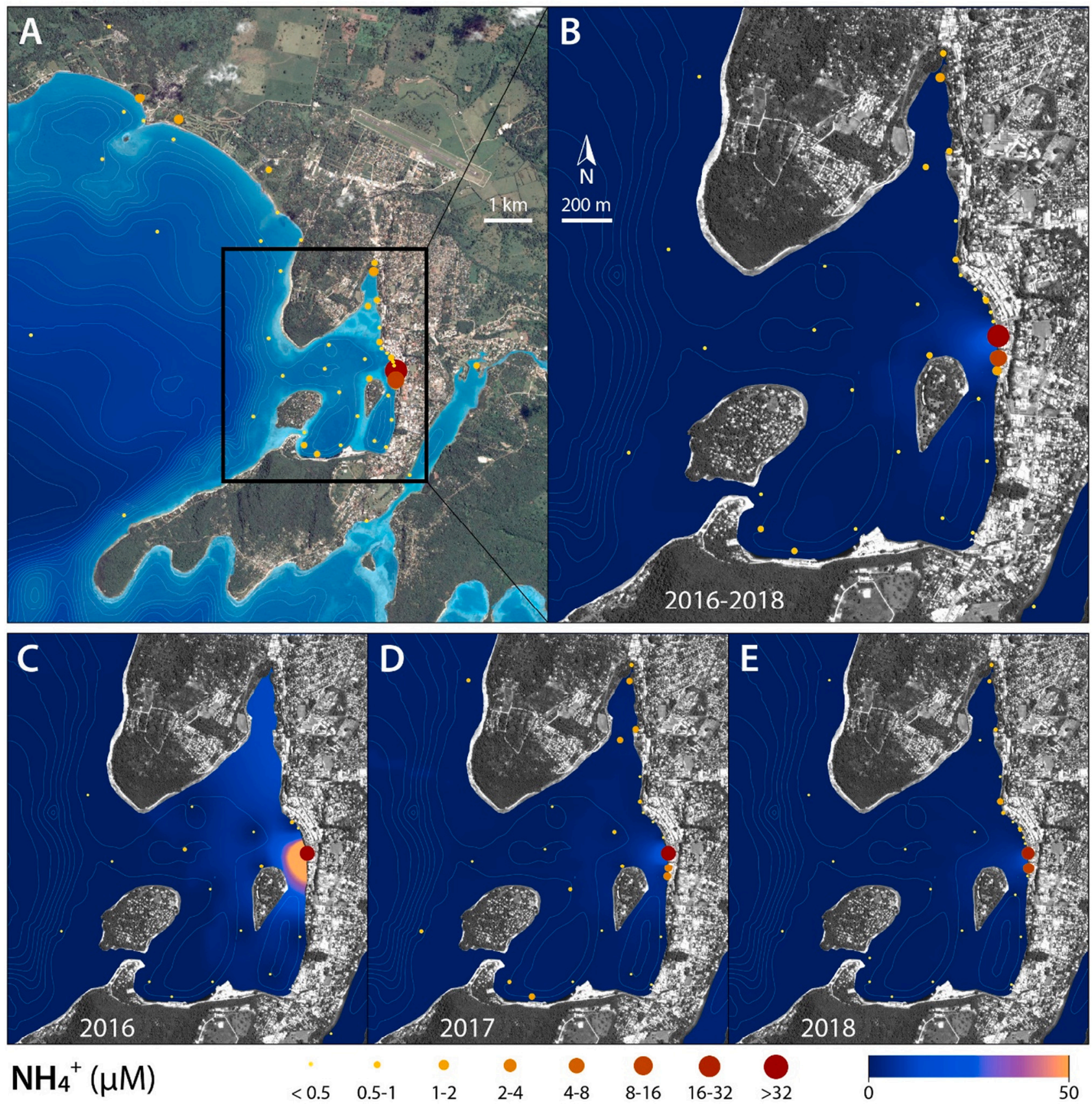

Fig. 7. (continued)

effective method to map water quality trends around Efate. Interpretation of these datasets was complicated by the high cloud coverage and low turbidity levels leading to bottom reflectance contamination in optically shallow waters. Their spatial resolution was too coarse for identifying sewage or riverine plumes. Remote sensing data are an important source of information for data-poor remote islands and acquisition of very high-resolution satellite data (available at a cost) or drone data would be useful in future studies, for example to validate the modelling results and progress the mapping of inshore effluent transport and associated risk in Efate. While the imageries tested were not adapted for the geographical scale of this baseline study, they were useful for mapping larger-scale patterns in water turbidity such as large filamentous algal blooms occurring offshore Efate during the austral summer conditions (Supplementary Fig. 3) which will be useful in wider regional studies. They have also been successfully used as part of the CME programme for mapping river plumes and sediment transport in other SIDS with larger rivers and sediment export rates (Devlin et al. 2019) and have been used successfully in many programs to map water quality gradients and impacts on coastal ecosystems (Petus et al., 2014; Petus et al., 2016).

The aim of the full research program (CMEP, 2017; CMEP, 2019c; Devlin et al., 2020; McManus et al., 2019) is to integrate different layers of data to provide an integrated assessment of water quality (Fig. 8). These additional datasets alongside the hydrodynamic modelling (Table 3) support the observations reported in this baseline study that the main anthropogenic pressures for Efate and more specifically Port 

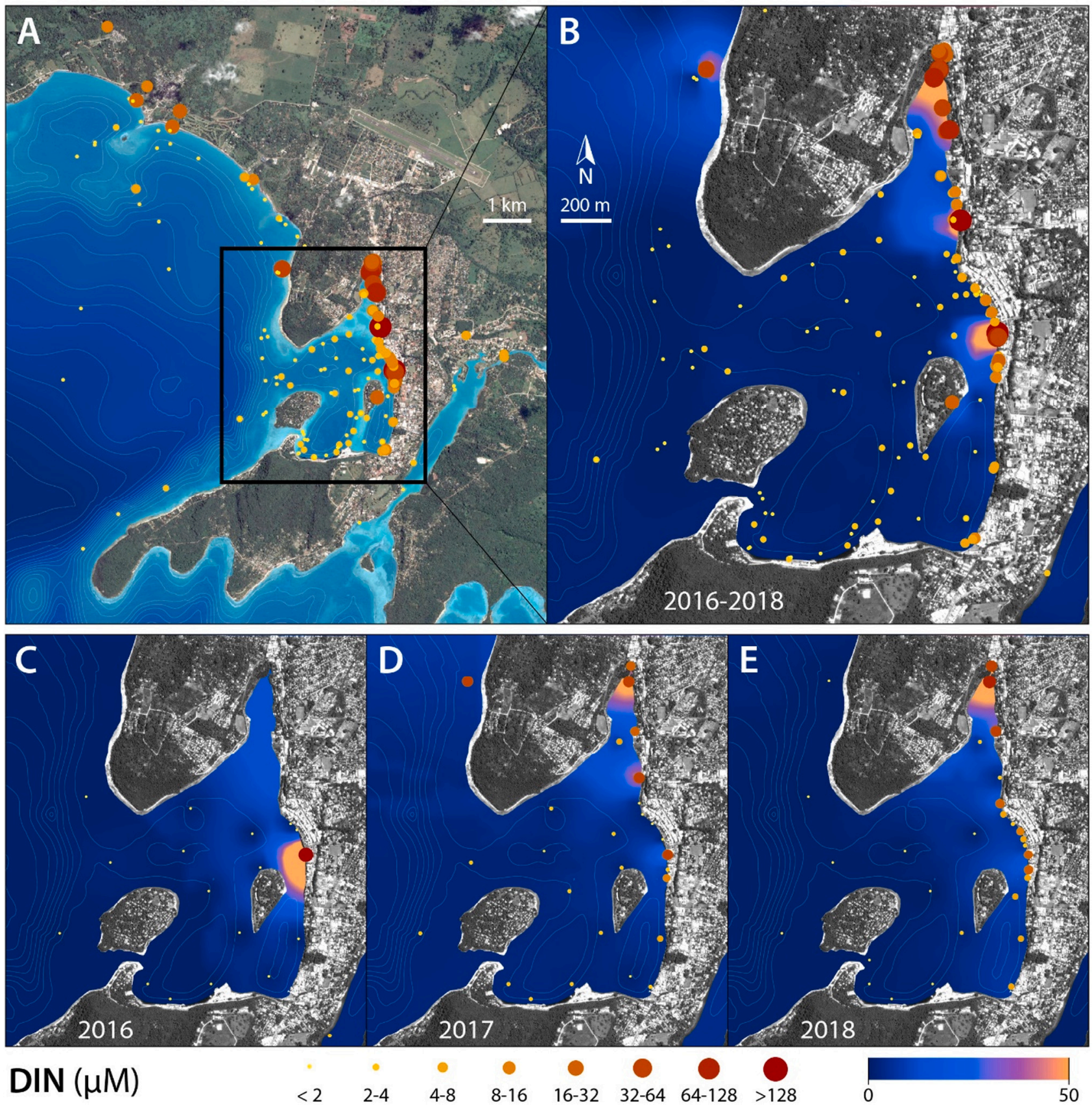

Fig. 7. (continued)

Vila, comes from diffuse and chronic (sewage and industrial) inputs associated localised issues of sewage and industrial inputs into the coastal zone and potentially exacerbated through dissolved nutrients and sediments from agricultural run-off. These pressures are having localised impacts on the rivers and coastal systems and must be considered against national and global pressures of overfishing, habitat destruction, and climate change. Management is required around local scale pressures, with a greater understanding of how those local impacts interact with changing national and global pressures.

This programme collected many environmental parameters with an aim of facilitating the transfer of this information into a regional assessent of Pacific resilience (Devlin et al., 2020). The coastal areas in Efate and Tanna support many vulnerable ecosystems such as nearshore seagrass beds (Komugabe-Dixson et al., 2019) and coastal fisheries
(Leopold et al., 2013; Raubani et al., 2017). Other recreational activities, including beach swimming and inshore fishing are also at risk from the high microbial discharges impacting on human health (Devlin et al., 2020). The water quality programme adds to our understanding of resilience through the mapping of the extent of the nutrient and pollutant inputs into the coastal system. $\mathrm{NO}_{\mathrm{X}}$ and $\mathrm{NH}_{4}$ relate to eutrophication pressures with higher nutrients in coastal systems impacting on primary production, light and shading and dissolved oxygen concentrations. High nutrient concentrations are present in the coastal areas of Port Vila and generally linked to the outfalls from the Port Vila Drains. Lowest concentrations of dissolved nutrients were measured in the northern part of Efate and Tanna. Port Vila Bay is at highest risk for eutrophication due to the high concentrations of dissolved nutrients from the stormwater drains. There is a possibility that higher nutrient 
Table 3

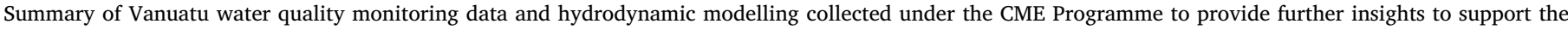

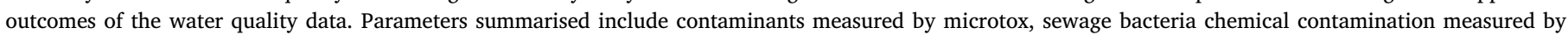
passive samples and application of a hydrodynamic model.

\begin{tabular}{|c|c|c|c|}
\hline Parameter & What does it tell us - issues for Vanuatu & Impacts on ecosystem resilience & Final assessment \\
\hline $\begin{array}{l}\text { Contaminant Impact } \\
\text { (Microtox) } \\
\text { Smith et al., } 2020\end{array}$ & $\begin{array}{l}\text { Microtox data shows combined impact for any } \\
\text { acutely toxic contaminants. Samples taken at } \\
\text { the areas with complex effluent inputs or where } \\
\text { industrial operations are occurring have highest } \\
\text { values. For example, the effluent outfall near } \\
\text { Port Vila market caused } 50 \% \text { reduction in } \\
\text { growth and a sample of the Tagabe River, which } \\
\text { discharges into Mele Bay, showed a reduction of } \\
\text { almost } 40 \% \text { (Smith et al., } 2020 \text { This river is } \\
\text { where some of the industrial sites discharge } \\
\text { their effluents. Further analysis of these high- } \\
\text { risk sites is recommended. }\end{array}$ & $\begin{array}{l}\text { Innovative sampling using in-situ } \\
\text { instrumentation can help define the areas of high } \\
\text { risk to environmental health. These sensors } \\
\text { respond to toxic chemicals rather than sewage } \\
\text { bacteria, or nutrient loading, and so provide a } \\
\text { measure of industrial, commercial, or } \\
\text { agricultural impacts. These data can identify } \\
\text { areas where combined pollutants are causing } \\
\text { impacts that may not be predictable from } \\
\text { individual contaminant concentrations. This } \\
\text { information can be used to determine areas } \\
\text { where the local ecology is being influenced by } \\
\text { the overall contaminant load. }\end{array}$ & $\begin{array}{l}\text { Microtox data has been collected for river and } \\
\text { seawater samples across a wide range of sites. In } \\
\text { general, the water at sites tested appeared to } \\
\text { have low overall toxicity, with some notable } \\
\text { exceptions. This provides an assessment of } \\
\text { current water column issues, but does not assess } \\
\text { sediment contamination, which can become an } \\
\text { issue during dredging or storms. The Tagabe } \\
\text { River and the effluent channel outside of the } \\
\text { market in Port Vila have been identified as areas } \\
\text { that need further investigation if the ecology of } \\
\text { the surrounding area is to be protected (Smith } \\
\text { et al., in review). }\end{array}$ \\
\hline $\begin{array}{l}\text { Sewage Bacteria } \\
\text { (Department of } \\
\text { Water Resources) }\end{array}$ & $\begin{array}{l}\text { Sporadic peaks in microbial contamination were } \\
\text { observed in Port Vila. Some samples failed } \\
\text { international bathing water standards. } \\
\text { However, restricted temporal coverage of the } \\
\text { microbial samples limits confidence in this } \\
\text { assessment. }\end{array}$ & $\begin{array}{l}\text { These samples are most appropriately taken in } \\
\text { key areas of contamination for example: in close } \\
\text { proximity of the stormwater drains in Port Vila. } \\
\text { Understanding of impacts can be developed } \\
\text { further through a pollution dispersion model } \\
\text { (e.g. Graham et al., 2020) Integration of in-situ } \\
\text { samples and the particle transport modelling is } \\
\text { key to resilience mapping related to human } \\
\text { health issues. }\end{array}$ & $\begin{array}{l}\text { Sewage contamination is a serious issue for } \\
\text { Vanuatu, as with all Pacific countries facing } \\
\text { increasing populations and a lack of adequate } \\
\text { sewage treatment infrastructure. The CME } \\
\text { Programme data was in partnership with the } \\
\text { Vanuatu Department of Water Resources and is } \\
\text { being used in a wider monitoring program. } \\
\text { Further monitoring is required to help prioritise } \\
\text { what mitigation is required to address human } \\
\text { health concerns. }\end{array}$ \\
\hline $\begin{array}{c}\text { Chemical Contaminants } \\
\text { Smith et al., } 2020\end{array}$ & $\begin{array}{l}\text { Passive samplers were used to quantify known } \\
\text { pollutants in the water at } 12 \text { sites around Efate. } \\
\text { This provided a list of chemicals of concern that } \\
\text { are making their way into the marine } \\
\text { environment, and identified the most impacted } \\
\text { areas. }\end{array}$ & $\begin{array}{l}\text { Passive samplers adsorb contaminants from the } \\
\text { environment over a period of days, which makes } \\
\text { them a better suited to observing the periodic } \\
\text { pollution events and concentrations influenced } \\
\text { by rainfall or tidal cycles than standard in situ } \\
\text { sampling. }\end{array}$ & $\begin{array}{l}\text { Certain chemicals, such as specific } \\
\text { hydrocarbons and pesticides, were observed at } \\
\text { concentrations of concern for human health and } \\
\text { the coastal ecosystems at some locations around } \\
\text { Port Vila. }\end{array}$ \\
\hline $\begin{array}{l}\text { Hydrodynamic } \\
\text { (pollutant) } \\
\text { modelling } \\
\text { (Graham et al., } \\
\text { 2020). }\end{array}$ & $\begin{array}{l}\text { Surface plumes of pollutant transport lead to } \\
\text { high surface concentrations at the coast. } \\
\text { Buoyant plumes flow along the coastline, and } \\
\text { high concentrations build up in enclosed } \\
\text { bays.Suggested control method include } \\
\text { consolidating existing outflows at depth off- } \\
\text { shore. }\end{array}$ & $\begin{array}{l}\text { Highest concentrations remain close to source, } \\
\text { with spread affected by bathymetry and } \\
\text { coastline. } \\
\text { Surface plumes lead to high surface } \\
\text { concentrations along the coast. } \\
\text { Highest concentrations are expected in the wet } \\
\text { season, due to increased outflows and favourable } \\
\text { winds. } \\
\text { Release at depth lowers surface concentrations, } \\
\text { but the impact is dependent on depth and } \\
\text { location of release. }\end{array}$ & $\begin{array}{l}\text { Highest concentrations remain close to coast, } \\
\text { close to source. Bathymetry and coastline affect } \\
\text { dispersal e.g. high concentrations build up in } \\
\text { shallow, enclosed bays. Highest concentrations } \\
\text { build up in Fatumaru Bay. Coastal ecosystems } \\
\text { will have reduced reslience due to high } \\
\text { pollutant exposure, which in turn will impact on } \\
\text { coastal amenities (tourism and swimming). }\end{array}$ \\
\hline
\end{tabular}

concentrations are impacting on coastal habitats such as seagrass beds through increased productivity and/or enhanced shading impacts (epiphytes on seagrass or light limitations). The higher values of $\mathrm{NH}_{4}$ around the Port Vila Drains highlight sewage and potential human health issues.

Whilst a small step in the need for detailed scientific information on Vanuatu's coastal water quality, the data presented in this study identifies some of the key issues facing Vanuatu that are representative of the broader Pacific coastal water quality issues. Whilst the focus of this paper is to report on the water quality data as a baseline dataset, it is part of a much larger programme, and should be considered in context of the many outcomes that have been delivered within that programme. One of the aims of the CME Programme was to map and report on ecosystem resilience in Pacific coastal waters which requires complex information on the interactions between pressures, drivers and state of Pacific ecosystems. Much remains to be done to understand how resilient processes and systems work and what we need to do to identify, protect and restore them. More data on water, human health and ecosystems is required for more informed understanding of ecosystem resilience (Table 3, Fig. 8).

Vanuatu, as with most other Pacific islands, faces global, national and local-scale challenges to its unique and valuable marine habitats (Bell et al., 2011; Brodie, 2016; Chape, 2006; Glynn et al., 2016; McIntyre and Heileman, 2005; Mimura, 2006; Waycott et al., 2011). The data set presented here provides a baseline against which future studies can be benchmarked. This is timely given the development of the port situated within Port Vila Bay and the associated increase in both tourism and cargo trade (Buckwell et al., 2018; Komugabe-Dixson et al., 2019; SPREP, 2018; Zari et al., 2020). Such information can be used to assess the success of mitigation measures (e.g. improvements in waste-water treatment or storm water runoff) or pollution reduction policies designed to better manage the coastal zone. Furthermore, these data help inform regional assessments of water quality (SPREP, 2018), climate change resilience reporting (CMEP, 2018; Komugabe-Dixson et al., 2019; Townhill et al., 2020) and reporting requirements to meet UN Sustainable Development Goals (Vanuatu, 2019). The data will also enable identification of pollution hotspots and start to provide evidence of plume behaviour for effluents. Viewed holistically and integrated with other datasets documenting environmental change, urbanisation and ecological resilience this will increase the local capacity to make more informed decisions with respect to environmental aspects of marine and coastal planning.

\section{CRediT authorship contribution statement}

All authors contributed to the manuscript. Michelle Devlin led the paper and contributed field work and data analysis. Carolyn Graves, Andy Smith, Brett Lyons, Caroline Petus and Dieter Tracey all co-authored the paper, carried out data analysis and contributed to the paper. Carolyn Graves, Andy Smith, Brett Lyons, Michael Maniel, Eryn 


\section{INTEGRATED ASSESSMENT OF WATER QUALITY}

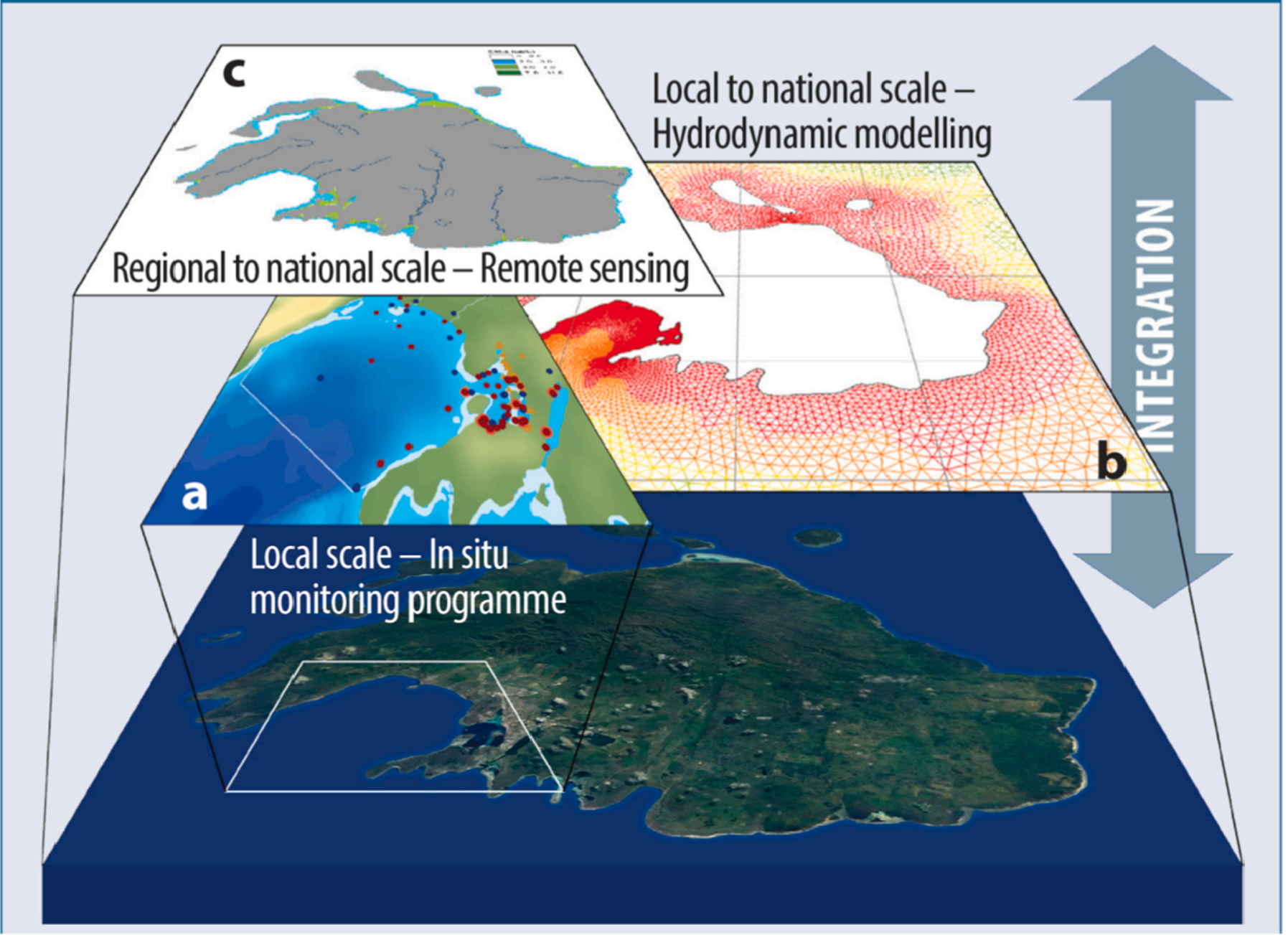

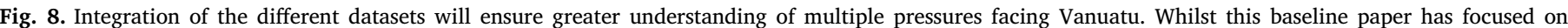

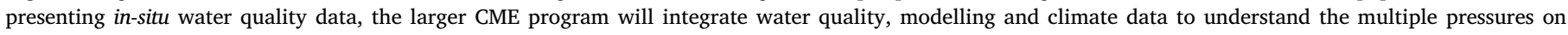
ensuring resilient communities, biota and habitats.

Hooper and Krishna Kotra contributed to the field work and in country laboratory analysis. Krishna Kotra supported the field work and concept and provided the laboratory space for the water quality analysis. Erie Samie provided data and guidance from the Department of Water Resources in Vanuatu.

\section{Declaration of competing interest}

The authors declare that they have no known competing financial interests or personal relationships that could have appeared to influence the work reported in this paper.

\section{Acknowledgments}

The authors thank The Vanuatu Department of Environmental Protection and Conservation for providing research permits to allow this study. We thank the Secretariat of the Pacific Regional Environment Programme, University of the South Pacific, Vanuatu Department of Water Resources, Vanuatu Environmental Science Society, Coasts Climate Oceans Consulting and their RESCCUE marine champions, and the people of Efate for their help and support. We thank Peter Sharry for his help and field assistance through Year 2 of this project. This study was funded by the UK Commonwealth Marine Economies Programme, which is part of the Conflict, Stability and Security Fund led by the former UK Foreign and Commonwealth Office (now Foreign Commonwealth \& Development Office). We thank the two anonymous reviewers for the valuable comments, which contributed to a significant improvement of the manuscript.

\section{Appendix A. Supplementary data}

Supplementary data to this article can be found online at https:// doi.org/10.1016/j.marpolbul.2020.111651.

\section{References}

Amato, D.W., Whittier, R.B., Dulai, H., Smith, C.M., 2020. Algal bioassays detect modeled loading of wastewater-derived nitrogen in coastal waters of O'AHU, HAWAI'I. Mar. Pollut. Bull. 150, 110668.

Anon, 2019. Vanuatu Environment - current issues [index mundi]. URL. https://www. indexmundi.com/vanuatu/environment_current_issues.html, Accessed date: 9 April 2020.

Anthony, K.R., Marshall, P.A., Abdulla, A., Beeden, R., Bergh, C., Black, R., Eakin, C.M., Game, E.T., Gooch, M., Graham, N.A., 2015. Operationalizing resilience for adaptive coral reef management under global environmental change. Glob. Chang. Biol. 21, 48-61. 
Barnes, M.D., Goodell, W., Whittier, R., Falinski, K.A., Callender, T., Htun, H., LeViol, C., Slay, H., Oleson, K.L., 2019. Decision analysis to support wastewater management in coral reef priority area. Mar. Pollut. Bull. 148, 16-29.

Bell, J.D., Johnson, J.E., Hobday, A.J., 2011. Vulnerability of Tropical Pacific Fisheries and Aquaculture to Climate Change. SPC FAME Digital Library.

Brodie, J.E., 2016. State of Marine Environment in the South Pacific Region. UNEP.

Brodie, J.E., Devlin, M., Haynes, D., Waterhouse, J., 2010. Assessment of the eutrophication status of the Great Barrier Reef lagoon (Australia). Biogeochemistry 106, 281-302.

Brodie, J., Waterhouse, J., Schaffelke, B., Johnson, J., Kroon, F., Thorburn, P., Rolfe, J., Lewis, S., Warne, M., Fabricius, K., 2013. Reef Water Quality Scientific Consensus Statement 2013. Department of the Premier and Cabinet. Queensland Government, Brisbane.

Brodie, G., Brodie, J., Maata, M., Peter, M., Otiawa, T., Devlin, M., 2020. Seagrass habitat in Tarawa Lagoon, Kiribati: service benefits and links to national priority issues. Mar. Pollut. Bull. 155, 111099.

Buckwell, A., Fleming, C., Smart, J., Mackey, B., Ware, D., Hallgren, W., Sahin, O., Nalau, J., 2018. Valuing Aggregated Ecosystem Services at a National and Regional Scale for Vanuatu Using a Remotely Operable, Rapid Assessment Methodology.

Carter, R., 1990. Hydraulic and Water Quality Studies, Erakor Lagoons and Port Vila Harbour, Vanuatu. South Pacific Applied Geoscience Commission.

Chape, S., 2006. Review of environmental issues in the pacific region and the role of the pacific regional environment programme. In: Workshop and Symposium on Collaboration for Sustainable Development of the Pacific Islands: Towards Effective e-Learning Systems on Environment, pp. 27-28.

CMEP, 2017. Commonwealth Marine Economies Programme Funded by UK Government Enabling safe and sustainable marine economies across Commonwealth Small Island Developing States. Vanuatu Country Review. Commonwealth Marine Economies Programme Final Report. https://assets.publishing.service.gov.uk/government/ uploads/system/uploads/attachment_data/file/806085/Commonwealth_Marine Economies_Programme_-_Vanuatu_Country_review.pdf.

CMEP, 2018. Pacific Marine Climate Change Report Card 2018. Commonwealth Marine Economies Programme, UK. https://www.gov.uk/government/publications/ commonwealth-marine-economies-cme-programme-pacific-marine-climate-changereport-card-and-scientific-reviews.

Devlin, M., Best, M., Haynes, D., 2007. Implementation of the Water Framework Directive in European marine waters. Mar. Pollut. Bull. 55, 1-2.

CMEP, 2019a. Seagrass Surveys Efate, Vanuatu (2017-2018). Newsletter. Commonwealth Marine Economies Programme. https://assets.publishing.service. gov.uk/government/uploads/system/uploads/attachment_data/file/837345/ Seagrass_Newletter_2017_to_2018.pdf.

CMEP, 2019b. Preliminary Outcomes of an Integrated Water Quality Assessment for Port Vila, Efate Vanuatu (2017-2018): Commonwealth Marine Economies Programme. CMEP Newsletter. https://www.sprep.org/pebacc/user-eba-links.

CMEP, 2019c. Seagrass Surveys Efate, Vanuatu (2017-2018): Summary. Commonwealth Marine Economies Programme. Cefas 2019. Commonwealth Marine Economies Programme Newsletter. https://assets.publishing.service.gov.uk/government/ uploads/system/uploads/attachment_data/file/835703/Seagrass_SummaryCard.pdf.

Devlin, M., Bacon, J., Haverson, D., Graham, J., Smith, A., Bremner, J., Petus, C., Townhill, B., Howes, E., Tracey, D., 2018. Pacific Water Quality and Resilience Framework-Year 2 Report. Commonwealth Marine Economies Programme Year 2 Final Report. Cefas, UK.

Devlin, M.J., Smith, A.J., Graves, C.A., Petus, C., Tracey, D., Maniel, M., Hooper, E., Graham, J.A., Samie, E., Kotra, K., Lyons, B.P. (2020). Vanuatu Water Quality Dataset - 2016-2018. Cefas, UK. vol. V1. doi:10.14466CefasDataHub.107.

Donnelly, K., Barber, M., Rizvi, S., 2012. Oceans of Innovation: The Atlantic, the Pacific, Global Leadership and the Future of Education. Penguin UK.

FAO, 2016. AQUASTAT - FAO's global information system on water and agriculture. http://www.fao.org/aquastat/en/countries-and-basins/country-profiles/country/ VUT.

Foden, J., Devlin, M.J., Mills, D.K., Malcolm, S.J., 2010. Searching for undesirable disturbance: an application of the OSPAR eutrophication assessment method to marine waters of England and Wales. Biogeochemistry 106, 157-175.

Fujita, M., Suzuki, J., Sato, D., Kuwahara, Y., Yokoki, H., Kayanne, H., 2013. Anthropogenic impacts on water quality of the lagoonal coast of Fongafale Islet, Funafuti Atoll, Tuvalu. Sustain. Sci. 8, 381-390.

Fulweiler, R.W., Rabalais, N.N., Heiskanen, A.S., 2012. The eutrophication commandments. Mar. Pollut. Bull. 64, 1997-1999.

Glynn, P.W., Manzello, D.P., Enochs, I.C., 2016. Coral Reefs of the Eastern Tropical Pacific: Persistence and Loss in a Dynamic Environment. Springer.

Graham, J.A., Haverson, D., Bacon, J., 2020. Modelling pollution dispersal around Solomon Islands and Vanuatu. Mar. Pollut. Bull. 150, 110589.

Greenhill, A.R., Mutreja, A., Bulach, D., Belousoff, M.J., Jonduo, M.H., Collins, D.A., Kas, M.P., Wapling, J., Seemann, T., Lafana, A., 2019. Wave 2 strains of atypical Vibrio cholerae El Tor caused the 2009-2011 cholera outbreak in Papua New Guinea. Microbial genomics 5 .

GSH, 2020. Vanuatu Sustainability Issues, in: Hub, G.S. (Ed.), https://www. globalsustainabilityhub.org/vanuatu-sustainability-issues/.

Herrera-Silveira, J.A., Comin, F.A., Aranda-Cirerol, N., Troccoli, L., Capurro, L., 2004. Coastal water quality assessment in the Yucatan Peninsula: management implications. Ocean \& Coastal Management 47, 625-639.

Islam, M.S., Tanaka, M., 2004. Impacts of pollution on coastal and marine ecosystems including coastal and marine fisheries and approach for management: a review and synthesis. Mar. Pollut. Bull. 48, 624-649.

Jeffrey, S.t., Humphrey, G., 1975. New spectrophotometric equations for determining chlorophylls a, b, c1 and c2 in higher plants, algae and natural phytoplankton.
Biochem. Physiol. Pflanz. 167, 191-194.

Johnson, J.E., Allain, V., Basel, B., Bell, J.D., Chin, A., Dutra, L.X., Hooper, E., Loubser, D., Lough, J., Moore, B.R., 2020. Impacts of climate change on marine resources in the Pacific island region, climate change and impacts in the Pacific. Springer, pp. 359-402.

Kenter, J.O., Hyde, T., Christie, M., Fazey, I., 2011. The importance of deliberation in valuing ecosystem services in developing countries-evidence from the Solomon Islands. Glob. Environ. Chang. 21, 505-521.

Komugabe-Dixson, A.F., de Ville, N.S., Trundle, A., McEvoy, D., 2019. Environmental change, urbanisation, and socio-ecological resilience in the Pacific: community narratives from Port Vila, Vanuatu. Ecosystem Services 39, 100973.

Koshy, K., Adeel, Z., Lal, M., Mataki, M., 2006. Impacts of Pollutants in the Asia-Pacific Region, Global Change and Integrated Coastal Management. Springer, pp. 231-276.

Leopold, M., Beckensteiner, J., Kaltavara, J., Raubani, J., Caillon, S., 2013. Communitybased management of near-shore fisheries in Vanuatu: what works? Mar. Policy 42, 167-176.

MacNeil, M.A., Mellin, C., Matthews, S., Wolff, N.H., McClanahan, T.R., Devlin, M., Drovandi, C., Mengersen, K., Graham, N.A.J., 2019. Water quality mediates resilience on the Great Barrier Reef. In: Nature Ecology \& Evolution.

Mallin, M.A., Williams, K.E., Esham, E.C., Lowe, R.P., 2000. Effect of human developmen on bacteriological water quality in coastal watersheds. Ecol. Appl. 10, 1047-1056.

Mansilha, C.R., Coelho, C.A., Heitor, A.M., Amado, J., Martins, J.P., Gameiro, P., 2009. Bathing waters: new directive, new standards, new quality approach. Mar. Pollut. Bull. 58, 1562-1565.

Mateo-Sagasta, J., Zadeh, S.M., Tural, H., 2017. Water pollution from agriculture: a global review. In: Food and Agriculture Organization of the United Nations Rome, a.t.I.W.M.I.o.b.o.t.W.L.a.E.r.p.C, (Colombo).

McIntyre, M., Heileman, S., 2005. Pacific Environment Outlook. UNEP/Earthprint.

Mcleod, E., Bruton-Adams, M., Förster, J., Franco, C., Gaines, G., Gorong, B., James, R., Posing-Kulwaum, G., Tara, M., Terk, E., 2019. Lessons from the Pacific Islands-adapting to climate change by supporting social and ecological resilience. Front. Mar. Sci. 6.289, 1-7. https://doi.org/10.3389/fmars.2019.00289.

McManus, E., Collins, M., Yates, O., Sanders, M., Townhill, B., Mangi, S., Tyllianakis, E., 2019. Commonwealth SIDS and UK Overseas Territories sustainable fisheries programmes: an overview of projects and benefits of official development assistance funding. Mar. Policy 107, 103437.

Mimura, N., 2006. State of the Environment in the Asia and Pacific Coastal Zones and Effects of Global Change, Global Change and Integrated Coastal Management. Springer, pp. 17-38.

Morrison, A., 2016. An Evaluation of a World Vision Water, Sanitation, and Hygiene (WASH) Project in Tanna, Vanuatu. University of Otago.

Mosley, L.M., Aalbersberg, W.G., 2003. Nutrient levels in sea and river water along the 'Coral Coast'of Viti Levu, Fiji. The South Pacific Journal of Natural and Applied Sciences 21, 35-40.

Muckle, A., Newbury, C., Ballantyne, T., Borofsky, R., Armitage, D., Bashford, A., 2015. Pacific Histories: Ocean, Land, People. Taylor \& Francis.

Müller, A., Österlund, H., Marsalek, J., Viklander, M., 2019. The pollution conveyed by urban runoff: a review of sources. Sci. Total Environ. 136125.

Naidu, S., Aalbersberg, W.G., Brodie, J., Fuavao, V., Maata, M., Morrison, R., NaqasimaSobey, M., Whippy, P., 1991. Water Quality Studies on Selected South Pacific Lagoons.

Ortiz, J.-C., Wolff, N.H., Anthony, K.R., Devlin, M., Lewis, S., Mumby, P.J., 2018. Impaired recovery of the Great Barrier Reef under cumulative stress. Sci. Adv. 4, eaar6127.

Palanaippan, M., Gleick, P.H., Allen, L., Cohen, M.J., Christian-Smith, J., Smith, C., 2017. Clearing the Waters: A Focus on Water Quality Solutions. United Nations Environment Programme.

Parsons, T.R., 2013. A Manual of Chemical \& Biological Methods for Seawater Analysis. Elsevier.

Petus, C., da Silva, E.T., Devlin, M., Wenger, A.S., Álvarez-Romero, J.G., 2014. Using MODIS data for mapping of water types within river plumes in the Great Barrier Reef, Australia: towards the production of river plume risk maps for reef and seagrass ecosystems. J. Environ. Manag. 137, 163-177.

Petus, C., Devlin, M., Thompson, A., McKenzie, L., Teixeira da Silva, E., Collier, C., Tracey, D., Martin, K., 2016. Estimating the exposure of coral reefs and seagrass meadows to land-sourced contaminants in river flood plumes of the Great Barrier Reef: validating a simple satellite risk framework with environmental data. Remote Sens. 8, 210 .

Poustie, M.S., Deletic, A., 2014. Modeling integrated urban water systems in developing countries: case study of Port Vila, Vanuatu. Ambio 43, 1093-1111.

Poustie, M.S., Frantzeskaki, N., Brown, R.R., 2016. A transition scenario for leapfrogging to a sustainable urban water future in Port Vila, Vanuatu. Technol. Forecast. Soc. Chang. 105, 129-139.

Quimpo, T.J.R., Ligson, C.A., Manogan, D.P., Requilme, J.N.C., Albelda, R.L., Conaco, C., Cabaitan, P.C., 2020. Fish farm effluents alter reef benthic assemblages and reduce coral settlement. Mar. Pollut. Bull. 153, 111025.

Raubani, J., Eriksson, H., Neihapi, P.T., Baereleo, R.T., Amos, M., Pakoa, K., Gereva, S., Nimoho, G., Andrew, N., 2017. Past experiences and the refinement of Vanuatu's model for supporting community-based fisheries management. Knowl. Manag. Aquat. Ecosyst. 38, 3-13.

Ryle, V., Wellington, J., 1982. Reduction Column for Automated Determination of Nitrates. Analytical Laboratory Note.

Salpin, C., Onwuasoanya, V., Bourrel, M., Swaddling, A., 2018. Marine scientific research in pacific small island developing states. Mar. Policy 95, 363-371.

Singh, S., Mosley, L.M., 2003. Trace metal levels in drinking water on Viti Levu, Fiji Islands. The South Pacific Journal of Natural and Applied Sciences 21, 31-34. 
Sivyer, D., Pearce, D., Greenwood, N., Hull, T., Fritton, E., Sciven, M., Mills, D., Malcolm, S., Keable, J., 2016. ESM2 Profiler/mini CTD Logger. Cefas, UK. vol. V1 Cefas DataHub.

Smith J, A, Barber, J, Davis, S, Jones, C, Kotra, K, Lyons P, B, Mataki, M, Devlin J, M, 2020. Aquatic Contaminants in Solomon Islands and Vanuatu: Evidence from Passive samplers and Microtox toxicity assessment. Marine Pollution Bulletin, MPB-D-2000995 In this issue.

SPREP, 2018. Planning for Ecosystem-Based Adaptation in Port Vila, Vanuatu., A Synthesis Report by the Secretariat of the Pacific Regional Environment Programme, Apia, Samoa. pp. 16.

String, G.M., Singleton, R.I., Mirindi, P.N., Lantagne, D.S., 2020. Operational research on rural, community-managed Water Safety Plans: case study results from implementations in India, DRC, Fiji, and Vanuatu. Water Res. 170, 115288.

Torno, H.C., Marsalek, J., Desbordes, M., 2013. Urban Runoff Pollution. Springer Science \& Business Media.

Townhill, B.L., Hills, J., Murray, P.A., Nichols, K., Pringle, P., Buckley, P., 2020. Communicating marine climate change impacts in the Caribbean and Pacific regions. Mar. Pollut. Bull. 150, 110709.

Tsamenyi, B.M., Jit, J., 2011. Evaluation of the Pacific Oceanscape to Manage the Pacific Islands and Ocean Environment.

Tyllianakis, E., Grilli, G., Gibson, D., Ferrini, S., Conejo-Watt, H., Luisetti, T., 2019. Policy options to achieve culturally-aware and environmentally-sustainable tourism in Fiji.
Mar. Pollut. Bull. 148, 107-115.

UNEP, 1999. (United Nations Environment Program) Overview of Land Based Sources and Activities Affecting the Marine Environment in the ROPME Sea Area., UNEPRegional Sea Reports and Studies No. 168.

Valderrama, J.C., 1981. The simultaneous analysis of total nitrogen and total phosphorus in natural waters. Mar. Chem. 10, 109-122.

Vanuatu, G.o., 2019. Republic of Vanuatu Voluntary National Review, 2019. https:// sustainabledevelopment.un.org/content/documents/23336Republic_of_Vanuatu_ VNR 2019.pdf.

Waycott, M., McKenzie, L.J., Mellors, J.E., Ellison, J.C., Sheaves, M.T., Collier, C. Schwarz, A.-M., 2011. Vulnerability of Mangroves, Seagrasses and Intertidal Flats in the Tropical Pacific to Climate Change.

Wolff, N.H., Mumby, P.J., Devlin, M., Anthony, K.R., 2018. Vulnerability of the Great Barrier Reef to climate change and local pressures. Glob. Chang. Biol. 24, 1978-1991.

Yoshioka, R.M., Kim, C.J., Tracy, A.M., Most, R., Harvell, C.D., 2016. Linking sewage pollution and water quality to spatial patterns of Porites lobata growth anomalies in Puako, Hawaii. Mar. Pollut. Bull. 104, 313-321.

Zari, M.P., Blaschke, P.M., Jackson, B., Komugabe-Dixson, A., Livesey, C., Loubser, D.I., Gual, C.M.-A., Maxwell, D., Rastandeh, A., Renwick, J., 2020. Devising urban ecosystem-based adaptation (EbA) projects with developing nations: a case study of Port Vila, Vanuatu. Ocean \& Coastal Management 184, 105037. 